\title{
Creep of Annealed Nickel, Copper, and Two Nickel- Copper Alloys
}

\author{
William D. Jenkins and Carl R. Johnson
}

\begin{abstract}
Creep tests were made in tension under constant loads at temperatures of $300^{\circ}, 700^{\circ}$, and $900^{\circ} \mathrm{F}$ on initially annealed specimens of nickel, copper, and 70-percent-nickel-30-percent-copper and 30-percent-nickel-70-percent-copper alloys. Tests at $1,200^{\circ} \mathrm{F}$ were also made on the nickel and the two alloys, but not on the annealed copper as the resistance to creep of copper is relatively low at this temperature. The investigation included a study of the influence of rate of loading on the creep stress and of prior thermal-mechanical history on the creep behavior of the alloys at several selected temperatures. Contour and hardness surveys and metallographic examinations were also carried out on some of the fractured specimens to ascertain the effect of creep on the necking characteristics, hardnesses, and structures of the metals.
\end{abstract}

\section{Introduction}

The effects of temperature on the short-time tensile and some other properties of the same lots of nickel, copper, and nickel-copper alloys initially in the annealed and cold-drawn condition were discussed in previous publications $[1$ to 7$] .{ }^{1}$ Parker and Hazlett [8] made a comprehensive survey of the literature on the principles of solution hardening in relation to the tensile properties of nickel-copper alloys. Hazlett and Hansen [9] showed that the shape of the creep curves for nickel extended in tension was markedly altered by either prestraining or alloying. French and Hibbard [10] discussed the changes in lattice parameters and mechanical properties of copper introduced by alloying with nickel.

According to Barrett [11] nickel and copper form a continuous series of substitutional solid solutions. All alloys of the system consist of a face-centeredcubic lattice with copper and nickel atoms distributed at random on the lattice points. Nickel has nearly the same atomic size as copper and the presence of nickel atoms alter only slightly the copper lattice. However, Averbach [12] pointed out that recent researches show that solid solutions are not random; that the atoms are displaced from their lattice sites; and that the atoms neither retain their pure metal sizes nor assume the average size calculated from the alloy lattice parameter. There is considerable uncertainty concerning the role of strain energy in solutions

${ }^{1}$ Figures in brackets indicate the literature reference at the end of this paper. containing atoms of disparate sizes; the solutions, however, may be randomized by plastic flow.

The present study was made of the creep characteristics of nickel, copper, and two alloys of these metals as a part of a comprehensive investigation designed to evaluate the rheological properties of samples of these metals at temperatures ranging from $-320^{\circ}$ to $+1,700^{\circ} \mathrm{F}$. Special attention was directed towards an evaluation of the resistance to creep of the alloys in relation to that of the component metals.

\section{Metals, Apparatus, and Procedure}

The chemical composition and average grain size of the metals used in this investigation are shown in table 1. All the bars of each metal were processed from a single heat. The creep specimens of each metal were machined from one annealed bar to an 0.505 -in. diameter over a 2 -in. gage length. The preparation of the specimens and the apparatus used were described previously [1]. Essentially, each creep specimen was heated in air to the desired temperature and held at temperature $48 \mathrm{hr}$ before loading. Load increments, each equivalent to a stress value of $5,333 \mathrm{lb} / \mathrm{in}^{2}{ }^{2}$, were applied at $1-\mathrm{hr}$ intervals (hereafter designated as the "standard" rate of loading) until the desired stress was attained. This standard loading procedure was modified in those tests made to determine the influence of priorstrain history on the subsequent creep behavior. The prior history and procedures used in this series of experiments are described in tables 5 and 6 .

TABLE 1. Chemical composition (percentage by weight) of the metals and alloys used as determined by chemical, spectrochemical, and vacuum fusion analyses

\begin{tabular}{|c|c|c|c|c|c|c|c|c|c|c|c|c|c|}
\hline Metal & $\mathrm{C}$ & $\mathrm{Cu}$ & $\mathrm{Ni}$ & Co & $\mathrm{Fe}$ & $\mathrm{Mn}$ & $\mathrm{Si}$ & S & $\mathrm{Zn}$ & $\mathrm{O}_{2}$ & $\mathrm{~N}_{2}$ & $\mathrm{H}_{2}$ & $\begin{array}{l}\text { A verage } \\
\text { grain di- } \\
\text { ameter }\end{array}$ \\
\hline $\begin{array}{l}\text { Copper a }(\mathrm{OFHC}) \\
30 \%-\mathrm{Ni}-70 \%-\mathrm{Cu} \\
70 \%-\mathrm{Ni}-30 \%-\mathrm{Cu} \\
\text { Nickel }\end{array}$ & $\begin{array}{r}0.023 \\
.017 \\
.007\end{array}$ & $\begin{array}{l}\text { 99. } 99+ \\
68.84 \\
29.71 \\
0.009\end{array}$ & $\begin{array}{l}29.89 \\
70.08 \\
99.85\end{array}$ & $\begin{array}{l}0.04 \\
\text { (b) } \\
\text { (b) }\end{array}$ & $\begin{array}{l}0.50 \\
.01 \\
.04\end{array}$ & $\begin{array}{l}0.65 \\
.01 \\
.03\end{array}$ & $\begin{array}{l}0.003 \\
.12 \\
.11\end{array}$ & $\begin{array}{r}0.004 \\
.002 \\
.002\end{array}$ & $\begin{array}{l}0.09 \\
---\end{array}$ & $\begin{array}{r}0.001 \\
.001 \\
.002\end{array}$ & $\begin{array}{l}0.001 \\
.0015 \\
.001\end{array}$ & $\begin{array}{r}0.0002 \\
.0003 \\
.0002\end{array}$ & $\begin{array}{l}m m \\
0.025 \\
.040 \\
.025 \\
.045\end{array}$ \\
\hline
\end{tabular}

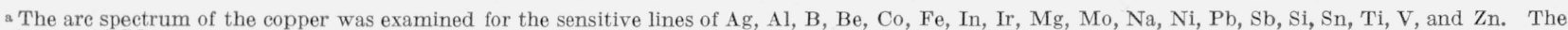
lines for $\mathrm{Ag}, \mathrm{Al}, \mathrm{Mg}$, and Si were identified and there was some indication of the presence of $\mathrm{Fe}, \mathrm{Ni}$, and $\mathrm{Pb}$.

b Not detected.

c Values obtained on specimens prepared from the annealed bars. 
The temperatures of the creep furnaces were controlled within $\pm 1^{\circ} \mathrm{F}$ of the desired temperatures over the specimen length and the probable error in measuring the extensions was less than 0.00002 in. Specimen contours were determined by measuring the diameter of the specimens at various distances from a fractured end. Rockwell hardness determinations were made along the longitudinal axis of specimens prepared by the usual procedures for making these measurements [1].

\section{Results and Discussion}

The results of creep tests made on specimens loaded at the standard rate are summarized in figures 1 to 20, and in tables 2, 3, and 4. Data obtained on specimens tested to determine the effect of prior-strain history on the creep properties are presented in figures 21 to 27 and in tables 5 and 6 . Values for the copper at $110^{\circ}$ and $300^{\circ} \mathrm{F}$ and for the nickel are not tabulated, as they were presented previously [1, 2, and 5].

\subsection{Influence of Temperature and Stress on Creep Behavior of Specimens Loaded at the Standard Rate}

\section{a. Stress-Strain Relations During Loading}

The effect of temperature on the stress-strain relations during loading is shown in figure 1. At each temperature, the general shape of the family of curves show that, after the start of deformation, the incremental changes of strain increased with each successive increment of stress. These values also increased with an increase in temperature. Thus, it is apparent that the strain hardening becomes less pronounced as the temperature is raised.

At each of the temperatures and at equal strains the strengths of the alloys were greater than those of the component metals. Furthermore, the differences in the rate of strain hardening between the component metals and the alloys were strongly dependent on temperature. A strengthening effect due to small strains associated with alloying the component materials has been described by Fisher [13].

\section{b. Effect of Temperature and Composition on Strain-Time and Creep Rate-Strain Relations}

The shape of the creep curves for all the specimens used in this investigation was, with a few exceptions, similar to those shown previously for copper [1, 2] and nickel [5].

Some of the strain-time curves of specimens of different compositions tested under identical conditions at $700^{\circ}, 900^{\circ}$, and $1,200^{\circ} \mathrm{F}$ are shown in figures 2,3 , and 4 . Due to differences in strengths of the metals, no identical tests were run at $300^{\circ} \mathrm{F}$. It is apparent that the resistance to deformation (fig. 2) of the alloys was greater than that of the pure nickel. Furthermore, the alloy containing 30 percent of copper was more creep resistant at all values of time than the alloy containing 70 percent of copper. Other examples of the effect of alloying the nickel with 70 percent of copper are shown in figure 3 for specimens tested at $700^{\circ}$ and $900^{\circ} \mathrm{F}$. These data indicate that the strengthening effects due to alloying are more pronounced as the time at stress is

TABLE 2. Summary of conditions used and results of creep tests on 70-percent-nickel-30-percent-copper alloy, initially as annealed

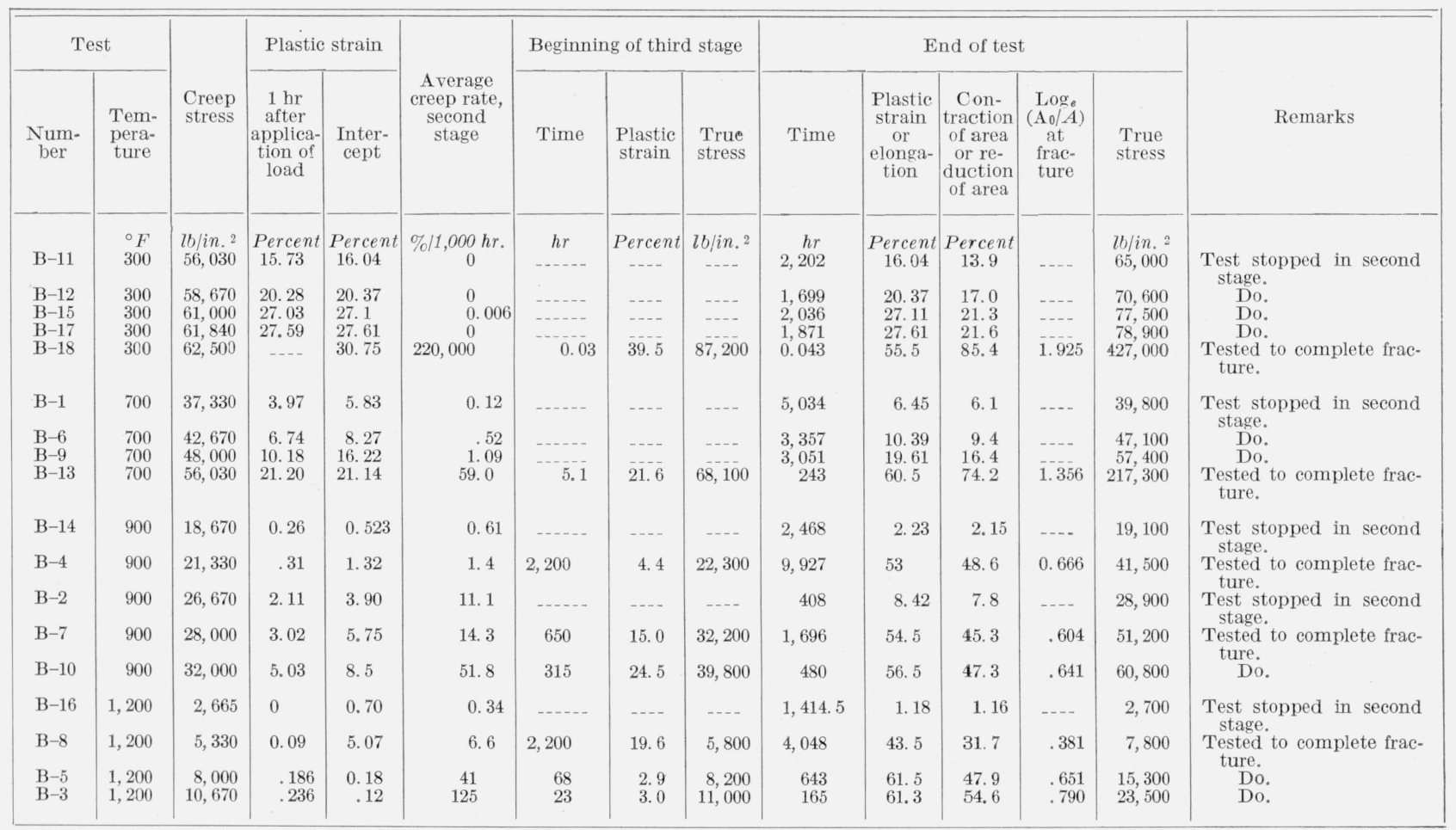


TABLE 3. Summary of conditions used and results of creep tests on 30-percent-nickel-70-percent-copper alloy, initially as annealed

\begin{tabular}{|c|c|c|c|c|c|c|c|c|c|c|c|c|c|c|}
\hline \multicolumn{2}{|c|}{ Test } & \multirow[b]{2}{*}{$\begin{array}{l}\text { Creep } \\
\text { stress }\end{array}$} & \multicolumn{2}{|c|}{ Plastic strain } & \multirow[b]{2}{*}{$\begin{array}{l}\text { Average } \\
\text { creep rate, } \\
\text { second } \\
\text { stage }\end{array}$} & \multicolumn{3}{|c|}{ Beginning of third stage } & \multicolumn{5}{|c|}{ End of test } & \multirow[b]{2}{*}{ Remarks } \\
\hline $\begin{array}{l}\text { Num- } \\
\text { ber }\end{array}$ & $\begin{array}{l}\text { Tem- } \\
\text { pera- } \\
\text { ture }\end{array}$ & & $\begin{array}{c}1 \mathrm{hr} \\
\text { after } \\
\text { applica- } \\
\text { tion of } \\
\text { load }\end{array}$ & $\begin{array}{l}\text { Inter- } \\
\text { cept }\end{array}$ & & Time & $\begin{array}{l}\text { Plastic } \\
\text { strain }\end{array}$ & $\begin{array}{l}\text { True } \\
\text { stress }\end{array}$ & Time & $\begin{array}{l}\text { Plastic } \\
\text { strain } \\
\text { or } \\
\text { elonga- } \\
\text { tion }\end{array}$ & $\begin{array}{l}\text { Con- } \\
\text { traction } \\
\text { of area } \\
\text { or re- } \\
\text { duction } \\
\text { of area }\end{array}$ & $\begin{array}{c}\log _{e} \\
\left(A_{0} / A\right) \\
\text { at } \\
\text { frac- } \\
\text { ture }\end{array}$ & $\begin{array}{l}\text { True } \\
\text { stress }\end{array}$ & \\
\hline $\mathrm{C}-24$ & $\begin{array}{c}\circ F \\
300\end{array}$ & $\begin{array}{l}l b / \text { in }^{2}{ }^{2} \\
37,330\end{array}$ & $\begin{array}{c}\text { Percent } \\
7.71\end{array}$ & $\begin{array}{c}\text { Percent } \\
\quad 7.74\end{array}$ & $\begin{array}{c}\% / 1,000 \mathrm{hr} . \\
0\end{array}$ & $h r$ & Percent & lb/in. ${ }^{2}$ & $\begin{array}{l}h r \\
1,507\end{array}$ & $\begin{array}{c}\text { Percent } \\
7.74\end{array}$ & $\begin{array}{c}\text { Percent } \\
7.2\end{array}$ & & $\begin{array}{l}l b / \text { in }^{2} \\
\quad 40,200\end{array}$ & $\begin{array}{l}\text { Test stopped in second } \\
\text { stage. }\end{array}$ \\
\hline C- -6 & 300 & 42,670 & 13.07 & 13. 16 & 0 & & & & 2,370 & 13. 16 & 11. 7 & & 48,300 & Do. \\
\hline $\begin{array}{l}\mathrm{C}-11 \\
\mathrm{C}-15\end{array}$ & $\begin{array}{l}300 \\
300\end{array}$ & $\begin{array}{l}46,000 \\
47,000\end{array}$ & $\begin{array}{l}19.69 \\
20.18\end{array}$ & $\begin{array}{l}19.84 \\
20.42\end{array}$ & $\begin{array}{l}0 \\
0\end{array}$ & & & & $\begin{array}{l}2,182 \\
2,340\end{array}$ & $\begin{array}{l}19.84 \\
20.42\end{array}$ & $\begin{array}{l}16.5 \\
16.9\end{array}$ & & $\begin{array}{l}55,200 \\
56,600\end{array}$ & Do. \\
\hline $\mathrm{C}-23$ & $\begin{array}{l}500 \\
300\end{array}$ & 47,200 & $\begin{array}{l}20.18 \\
20.6\end{array}$ & $\begin{array}{l}20.42 \\
20.7\end{array}$ & 0 & & & & 1,484 & 20.7 & $\begin{array}{l}10.9 \\
17.2\end{array}$ & & 57,000 & $\begin{array}{l}\text { Do. } \\
\text { Do. }\end{array}$ \\
\hline $\mathrm{C}-22$ & 300 & 47,350 & 23.57 & 23.45 & 510 & & & & 13 & 30.5 & 23.4 & & 61,800 & \\
\hline $\mathrm{C}-26$ & 300 & 47,650 & 47.0 & 23.1 & 6000 & 0.67 & 27.1 & 60,600 & 1 & 47.0 & 80.1 & 1. 612 & 238,900 & $\begin{array}{l}\text { Tested to complete frac- } \\
\text { ture. }\end{array}$ \\
\hline $\mathrm{C}-19$ & 700 & 26,670 & 3.58 & 6. 43 & 0.27 & & & & 3,330 & 7.73 & 6.8 & & 28,600 & $\begin{array}{l}\text { Test stopped in second } \\
\text { stage. }\end{array}$ \\
\hline $\mathrm{C}-4$ & 700 & 32,000 & 6.39 & 11.35 & 3. 63 & 4,020 & 26 & 40,300 & 5,346 & 46.0 & 51.7 & 0.728 & 66,300 & $\begin{array}{l}\text { Tested to complete frac- } \\
\text { ture. }\end{array}$ \\
\hline $\mathrm{C}-20$ & 700 & 34,670 & 8. 49 & 15.2 & 33.3 & 490 & 31.5 & 45,600 & 692 & 56.0 & 65.0 & 1.045 & 98,600 & Do. \\
\hline C-10 & 700 & 37,330 & 11. 92 & 16. 0 & 83.0 & 200 & 32.6 & 49,500 & 250 & 53.0 & 66.5 & 1. 092 & 111,300 & Do. \\
\hline $\mathrm{C}-16$ & 700 & 40,000 & 15.13 & 18.0 & 290 & 35 & 28.2 & 51,300 & 56 & 59.5 & 71.5 & 1. 253 & 140,000 & Do. \\
\hline $\mathrm{C}-21$ & 900 & 10,670 & 0.034 & 0.11 & 0.19 & & & & 2,345 & 0.57 & 0.57 & & 10,700 & Test stopped in second \\
\hline $\mathrm{C}-17$ & 900 & 13,335 & .21 & .8 & 2.1 & 1,800 & 4.6 & 13,900 & 3,860 & 10.12 & 9.2 & & 14,700 & Test stopped in third \\
\hline $\mathrm{C}-14$ & 900 & 16,000 & .91 & 2. 6 & 2.6 & 1,310 & 6.0 & 17,000 & 6,864 & 49.0 & 40.2 & 0.513 & 26,700 & $\begin{array}{l}\text { Tested to complete frac- } \\
\text { ture. }\end{array}$ \\
\hline C-8 & 900 & 18,670 & 1. 03 & 2. 3 & 9.5 & 1,300 & 14. 7 & 21,400 & 2,752 & 49.0 & 44. 5 & 0.590 & 33,700 & Do. \\
\hline $\mathrm{C}-7$ & 900 & 21,330 & 3. 58 & 6. 6 & 73.6 & 220 & 22.8 & 26,200 & 344 & 61.0 & 52.5 & 0.744 & 44,900 & Do. \\
\hline $\mathrm{C}-18$ & 900 & 24,000 & 6. 32 & 9.2 & 286 & 55 & 26.0 & 30,200 & 97 & 72.0 & 66.5 & 1.088 & 71,300 & Do. \\
\hline $\mathrm{C}-25$ & 1,200 & 1,450 & 0.03 & 0.15 & 1.54 & & & & 1,439 & 2. 37 & 2.3 & & 1,500 & Test stopped in second \\
\hline $\mathrm{C}-13$ & 1,200 & 1,700 & 0.13 & .29 & 2. 2 & 795 & 2 & 1,750 & 5. 206 & 10.22 & 9.3 & & 1,900 & $\begin{array}{l}\text { Test stopped in third } \\
\text { stage. }\end{array}$ \\
\hline C-9 & 1,200 & 2,665 & .07 & .34 & 4. 9 & 860 & 4. 6 & 2,800 & 944 & 5. 3 & 5. 0 & & 2,800 & Do. \\
\hline $\mathrm{C}-5$ & 1,200 & 5,330 & .10 & .03 & 58 & 45 & 2. 65 & 5,470 & 215 & 23 & 23.2 & 0.265 & 6,950 & $\begin{array}{l}\text { Tested to complete frac- } \\
\text { ture. }\end{array}$ \\
\hline $\mathrm{C}-12$ & 1,200 & 8,000 & .66 & .22 & 425 & 1. 2 & 0.75 & 8,060 & 29 & 28 & 28.6 & 0.336 & 11,200 & Do. \\
\hline
\end{tabular}

TABLE 4. Summary of conditions used and results of creep tests on copper, initially as annealed

\begin{tabular}{|c|c|c|c|c|c|c|c|c|c|c|c|c|c|c|}
\hline \multicolumn{2}{|c|}{ Test } & \multirow[b]{2}{*}{$\begin{array}{l}\text { Creep } \\
\text { stress }\end{array}$} & \multicolumn{2}{|c|}{ Plastic strain } & \multirow[b]{2}{*}{$\begin{array}{l}\text { A verage } \\
\text { creep rate, } \\
\text { second } \\
\text { stage }\end{array}$} & \multicolumn{3}{|c|}{ Beginning of third stage } & \multicolumn{5}{|c|}{ End of test } & \multirow[b]{2}{*}{ Remarks } \\
\hline $\begin{array}{c}\text { Num- } \\
\text { ber }\end{array}$ & $\begin{array}{l}\text { Tem- } \\
\text { pera- } \\
\text { ture }\end{array}$ & & $\begin{array}{l}1 \mathrm{hr} \\
\text { after } \\
\text { appli- } \\
\text { cation } \\
\text { of load }\end{array}$ & $\begin{array}{c}\text { Inter- } \\
\text { cept } \\
\text { at zero } \\
\text { time }\end{array}$ & & Time & $\begin{array}{l}\text { Plastic } \\
\text { strain }\end{array}$ & $\begin{array}{l}\text { True } \\
\text { stress }\end{array}$ & Time & $\begin{array}{l}\text { Elon- } \\
\text { gation }\end{array}$ & $\begin{array}{l}\text { Reduc- } \\
\text { tion of } \\
\text { area }\end{array}$ & $\begin{array}{l}\log e \\
\left(A_{0} / A\right) \\
\text { at frac- } \\
\text { ture }\end{array}$ & $\begin{array}{l}\text { True } \\
\text { stress }\end{array}$ & \\
\hline $\begin{array}{l}25 \\
34 \\
31 \\
30\end{array}$ & $\begin{array}{l}\circ F \\
700 \\
700 \\
700 \\
700\end{array}$ & $\begin{array}{r}l b / \text { in } .^{2} \\
2,100 \\
2,765 \\
5,330 \\
10,670\end{array}$ & $\begin{array}{c}\text { Percent } \\
0.02 \\
.07 \\
1.08 \\
10.52\end{array}$ & $\begin{array}{c}\text { Percent } \\
0.06 \\
.14 \\
1.11 \\
6.32\end{array}$ & $\begin{array}{c}\% / 1000 \mathrm{hr} \\
2.43 \\
5.04 \\
77 \\
4,200\end{array}$ & $\begin{array}{c}h r \\
450 \\
400 \\
15 \\
1.5\end{array}$ & $\begin{array}{l}\text { Percent } \\
1.15 \\
2.23 \\
2.25 \\
12.7\end{array}$ & $\begin{array}{r}l b / \text { in } .^{2} \\
2,100 \\
2,850 \\
5,450 \\
12,000\end{array}$ & $\begin{array}{r}h r \\
1,485 \\
797 \\
62.5 \\
2.4\end{array}$ & $\begin{array}{c}\text { Percent } \\
11 \\
11 \\
11 \\
25.5\end{array}$ & $\begin{array}{c}\text { Percent } \\
6.0 \\
6.9 \\
8.8 \\
21.3\end{array}$ & $\begin{array}{l}0.06 \\
0.07 \\
0.09 \\
0.24\end{array}$ & $\begin{array}{r}\text { lb/in. }{ }^{2} \\
2,250 \\
2,950 \\
5,850 \\
13,600\end{array}$ & $\begin{array}{l}\text { Tested to complete fracture. } \\
\text { Do. } \\
\text { Do. } \\
\text { Do. }\end{array}$ \\
\hline $\begin{array}{l}27 \\
33 \\
35 \\
32\end{array}$ & $\begin{array}{l}900 \\
900 \\
900 \\
900\end{array}$ & $\begin{array}{r}725 \\
1,450 \\
2,100 \\
2,755\end{array}$ & $\begin{array}{l}0.02 \\
.04 \\
.20 \\
.41\end{array}$ & $\begin{array}{l}0.02 \\
.05 \\
.21 \\
.6\end{array}$ & $\begin{array}{l}2.4 \\
9 \\
39.6 \\
80\end{array}$ & $\begin{array}{c}610 \\
140 \\
30 \\
6.5\end{array}$ & $\begin{array}{l}1.5 \\
1.3 \\
1.4 \\
1.17\end{array}$ & $\begin{array}{r}750 \\
1,500 \\
2,150 \\
2,800\end{array}$ & $\begin{array}{r}2,806 \\
452 \\
119 \\
39\end{array}$ & $\begin{array}{l}21 \\
15 \\
12.5 \\
14\end{array}$ & $\begin{array}{r}13.1 \\
8.9 \\
9.5 \\
10.3\end{array}$ & $\begin{array}{l}0.14 \\
0.09 \\
0.10 \\
0.11\end{array}$ & $\begin{array}{r}850 \\
1,600 \\
2,300 \\
3,100\end{array}$ & $\begin{array}{l}\text { Do. } \\
\text { Do. } \\
\text { Do. } \\
\text { Do. }\end{array}$ \\
\hline
\end{tabular}

increased and as the temperature is decreased. These observations agree with the results obtained on specimens of the two alloys tested at $700^{\circ}$ or $1,200^{\circ} \mathrm{F}$ (fig. 4). If the strengthening effects associated with alloying were due wholly to the lattice distortion or short-order arrangements, then it appears that the magnitude of these differences would not be as great. Apparently, some additional mechanism is partly responsible for this behavior. Cottrell [14] describes a process of this type and relates the properties found in substitutional solid solution alloys to the relative degree of interaction of moving dislocations with moving solute atoms. The solute atoms may act as barriers to the motion of dislocations. The Cottrell theory accounts for the alternating of dis- locations between slow and fast motions and may be applied to the serrated creep rate-strain curves shown in figures 5 and 6 . An additional prediction in this theory based on the creation of vacancies during straining at constant load, is that these curves (figs. 5 and 6 ) should be at first rather smooth, should become serrated as the strain is increased, and, at large strains, should again be comparatively smooth. An inspection of these data reveals that these effects do occur. Moreover, it appears that increasing the temperature from $900^{\circ}$ to $1,200^{\circ} \mathrm{F}$, increasing the stress at constant temperature, or increasing the copper content of the alloys tends to decrease the magnitude of the serrations.

It was not possible to deduce a simple mathe- 
TABLE 5. Effect of prior-strain history on creep of 70-percent-nickel-30-percent-copper alloy at $700^{\circ}, 900^{\circ}$, and $1,200^{\circ} \mathrm{F}$

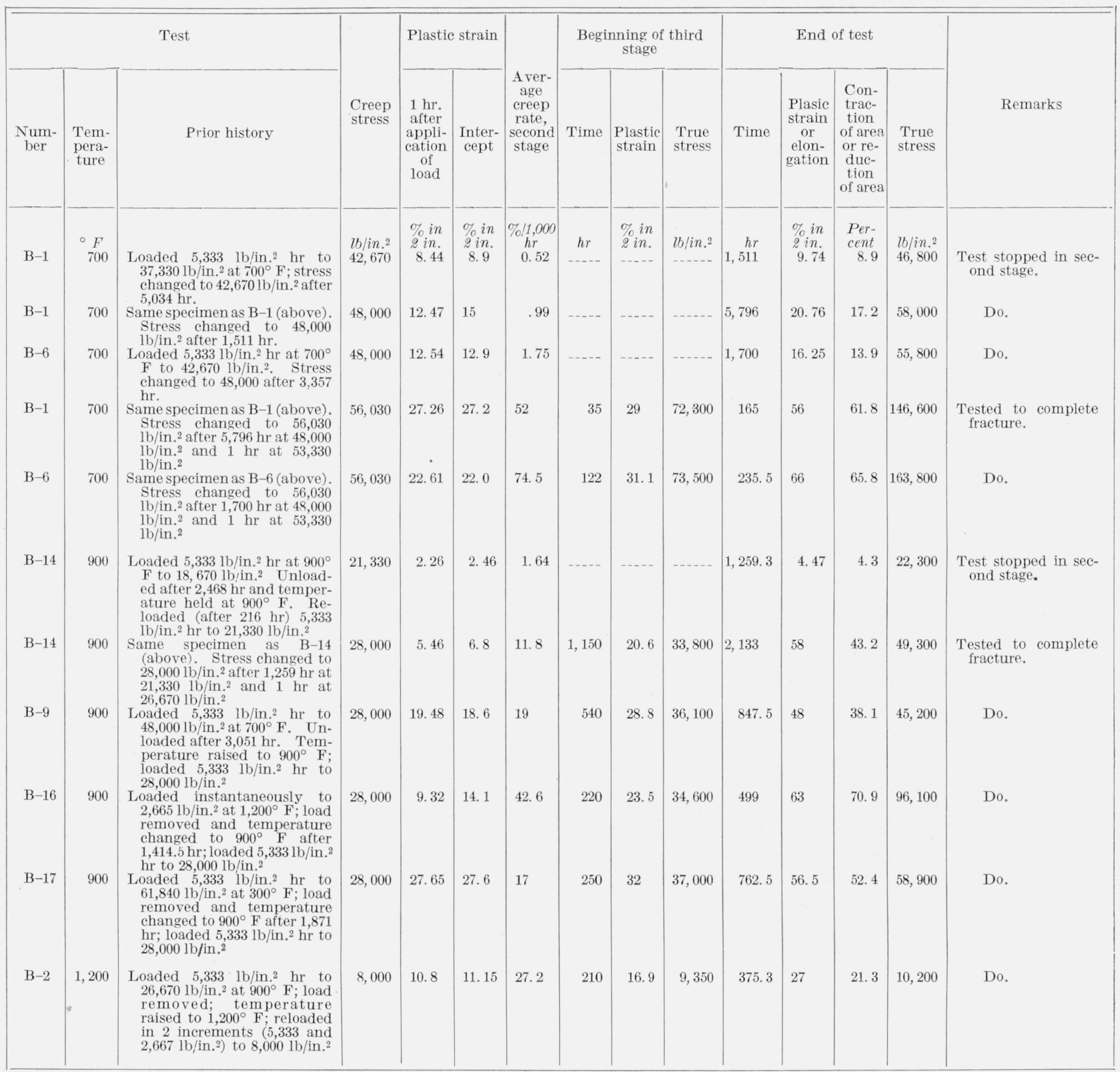

matical formula for describing the complete straintime curves. This observation is attributed to the fact that adequate parameters have not been determined for describing the complex structural changes that occur during the different stages of creep. Therefore, it was considered to be more fruitful to tabulate the data, as in tables 2,3 , and 4 , and then to analyze separately the data as applied to each of the various stages.

\section{c. First Stage of Creep}

The nature of the strain-time curve during the first stage (flow at a decelerating rate) has resulted in a number of mathematical analyses of this stage of the creep process. In general, a period of decreasing creep rate with increasing time was obtained in specimens used in this investigation. Several of the specimens used indicated the existence of an incubation period similar to those shown previously for some specimens of initially annealed nickel at $300^{\circ} \mathrm{F}$ [5]. The existence of this period in the alloys is also partly attributed to the magnitude of the final applied stress.

Probably the most complete analysis of the creep curves has been made by Andrade [15] who indicated that his data could be described by the equation:

$$
l=l_{0}\left(1+B t^{1 / 3}\right) e^{K t}
$$


TABLE 6. Effect of prior-strain history on creep of 30-percent-nickel-70-percent-copper alloy, initially as annealed

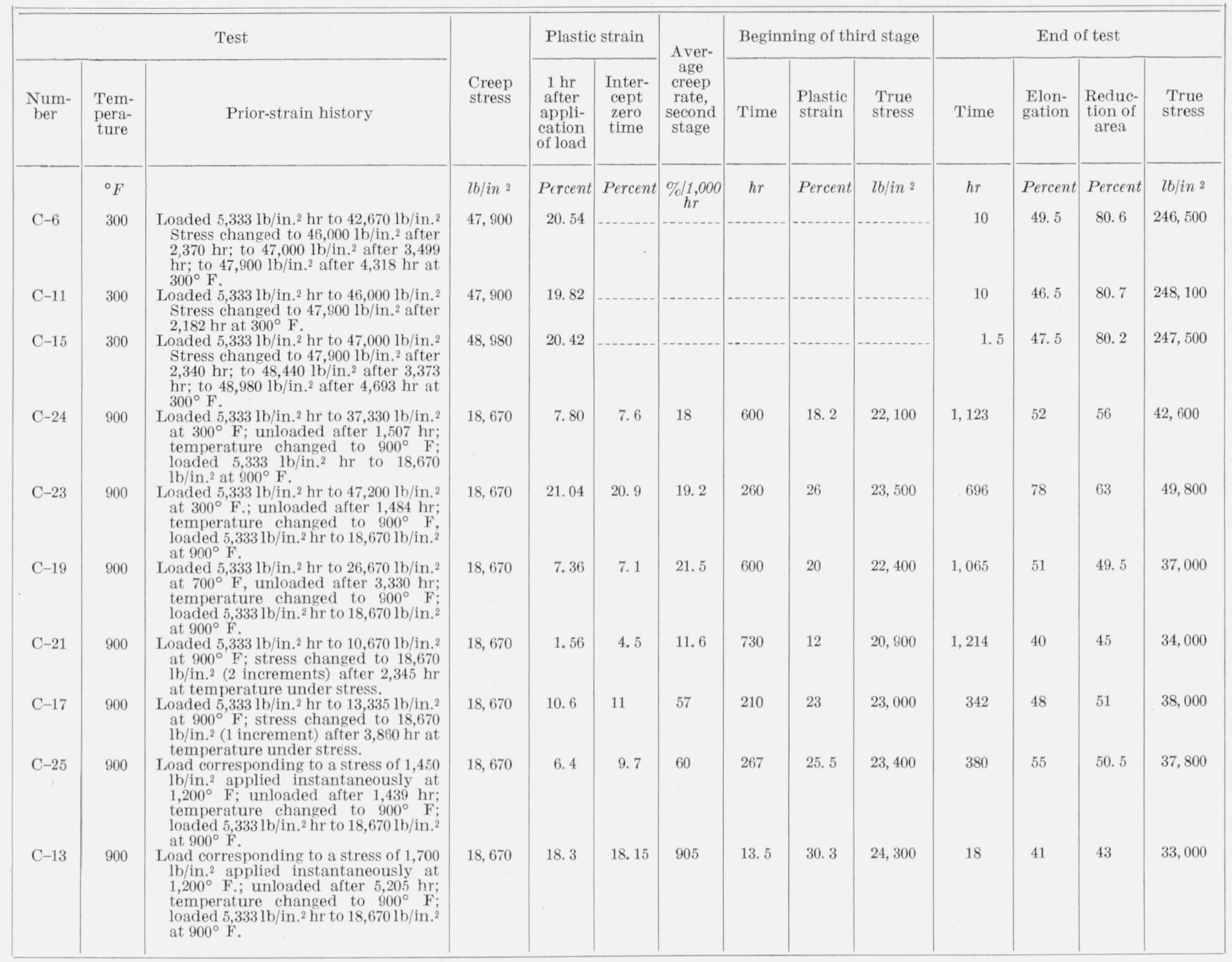

Where $l$ is the length of the specimen at time, $t$, and $l_{0}, B$, and $K$ are constants. The term, $B t^{1 / 3}$, was considered as representative of transient creep (essentially first stage) and the term, $K t$, represented the steady-state component (second stage of creep). If no steady-state component exists then $K$ would equal 0 and

or

$$
l=l_{0}\left(1+B t^{1 / 3}\right)
$$

$$
\frac{d l}{d t}=1 / 3 l_{0} B t^{-2 / 3}
$$

whence

where

$$
\log \dot{e}=-2 / 3 \log t+C_{1}
$$

$$
\dot{e}=\frac{1}{l_{0}} \frac{d l}{d t}=\text { creep rate. }
$$

With the exception of the data for several specimens, previously mentioned, a linear relation was obtained when the logarithm of the creep rate was plotted against the logarithm of the time during the first stage of creep. The relations between the slopes of the curves and the initially applied creep stresses are shown in figures $7 \mathrm{~A}$ and 8 . It is apparent that transient creep, as described by Andrade, did not exist as the slopes are dependent on stress, temperature, and nickel content. Obviously, the slopes are displaced to higher values (fig. 7A) as the temperatures are increased. No general trend was observed to describe the influence of alloying the nickel with copper (fig. 8).

The modified exhaustion theory of Davis and Thompson [16] is described by the equation

$$
\log (t \dot{e})=A+B \log e
$$

where $t=$ time, $e=$ creep rate, and $e=$ strain. Attempts were made to apply this formula to the data obtained for the 70-percent-Ni-30-percent-Cu alloy. However, the agreement was not as good as that previously recorded for nickel [5] as shown by the curves in figures $7 \mathrm{~B}$ and 9 . The values for the slopes in this analysis should be between +1 and $-\frac{1}{2}$. The effect of stress on the values of the slopes, for the 70-percent- $\mathrm{Ni}-30$-percent-Cu alloy is shown in figure $7 \mathrm{~B}$, and the influence of alloying the nickel 


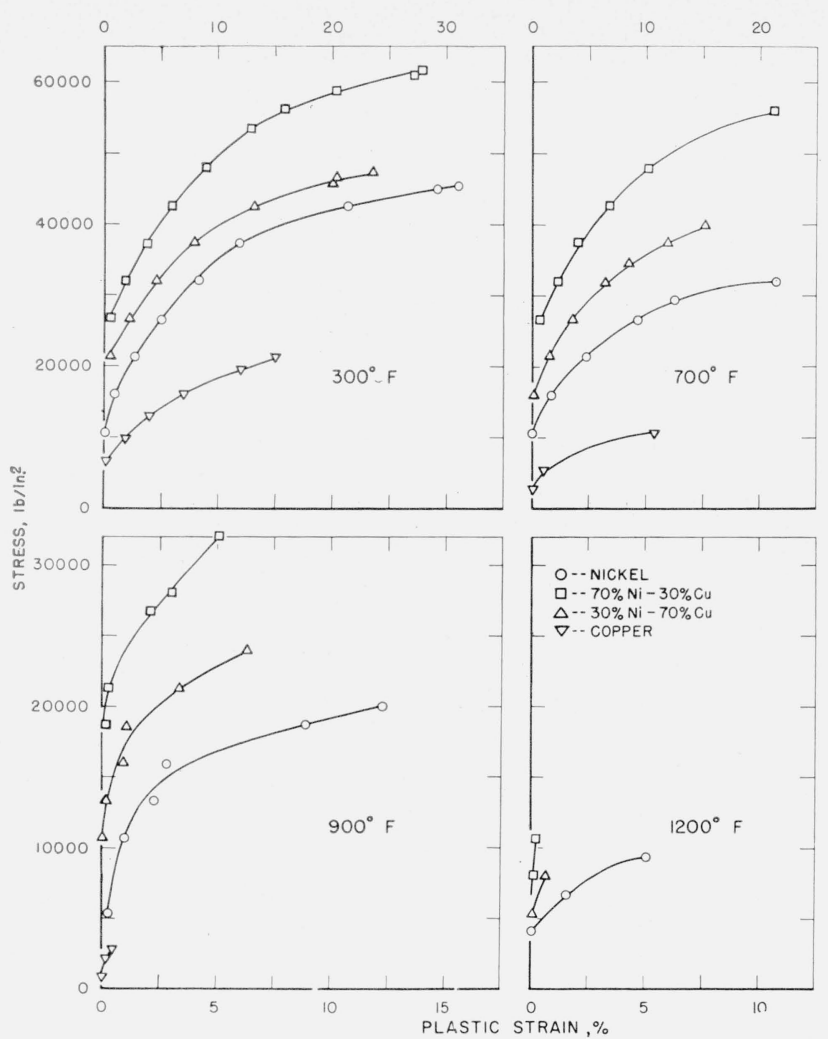

Figure 1. Stress-strain relations of specimens tested at different temperatures.

The strain values shown were those measured $1 \mathrm{hr}$ after application of the corresponding stress.

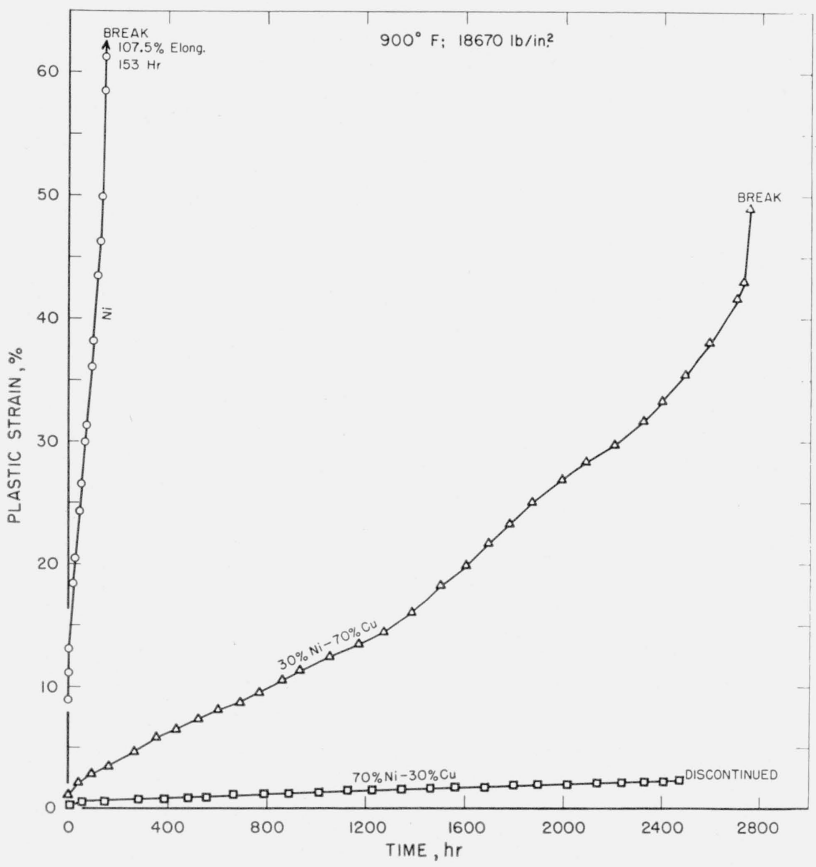

FIGURE 2. Strain-time relations of specimens tested at $900^{\circ} \mathrm{F}$ with a stress of $18,6 \% 0 \mathrm{lb} / \mathrm{in}^{2}$.

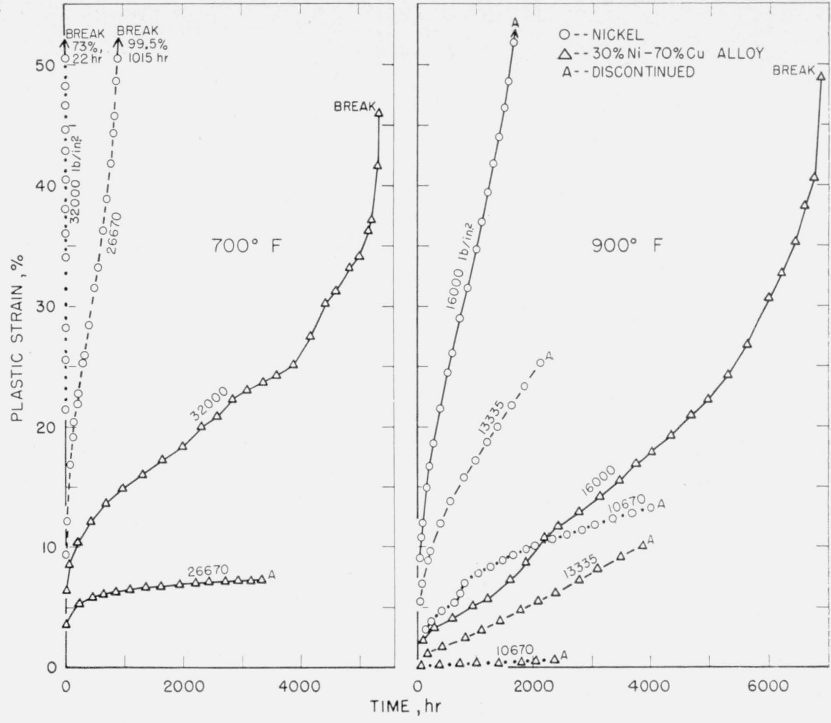

FIGURE 3. Strain-time relations of specimens tested at $700^{\circ}$ or $900^{\circ} \mathrm{F}$.

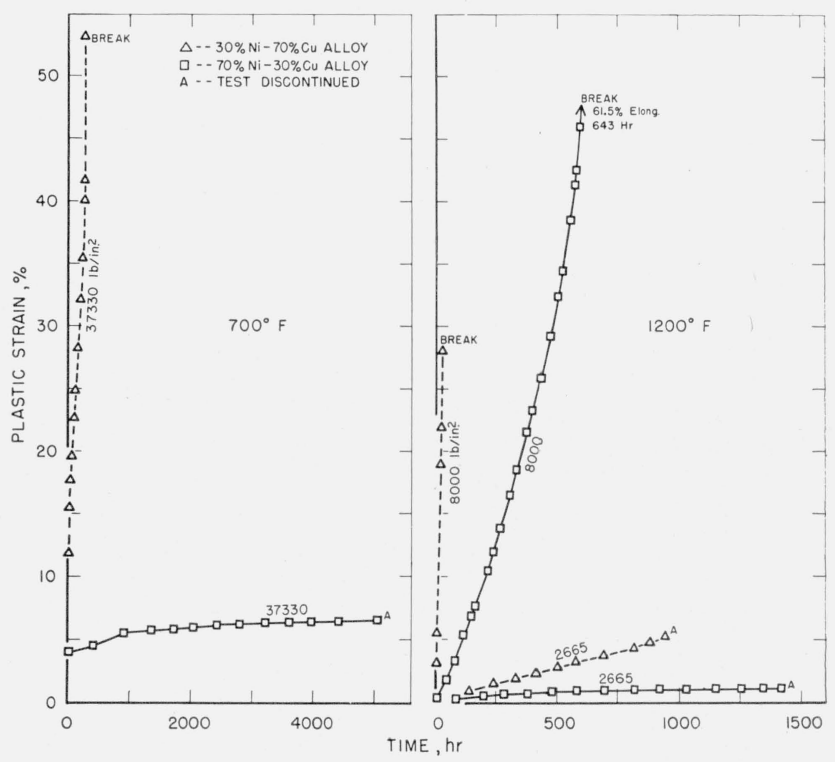

Figure 4. Strain-time relations for two specimens of $\mathrm{Cu}-\mathrm{Ni}$ alloys tested at $700^{\circ}$ or $1,200^{\circ} \mathrm{F}$ with different stresses.

with 30 percent of copper is shown by the data reproduced in figure 9. For the alloy (fig. 7B), it appears that the slopes increase with increasing temperature (stress constant) or with increasing stress (temperature constant).

The shapes of the curves appear to indicate that the deformation process changes somewhat with variations in temperature and stress. With the exception of the data obtained at $1,200^{\circ} \mathrm{F}$ (fig. 9), alloying the nickel displaced the values of the slopes to lower values. Apparently, the solute atoms that cause a strengthening effect in the alloy at low temperatures are less effective strengtheners as the temperature is raised. 
The stress dependence of creep rate in the first stage of the 70-percent-Ni-30-percent-Cu alloy is shown in figure 10. Nadai and McVetty [17] indicated that this relation could be expressed by an equation of the form

$$
\dot{e}=\dot{e}_{0} \sinh \left(\frac{\sigma}{\sigma_{0}}\right)
$$

where $\dot{e}=$ the creep rate, $\sigma=$ stress, and $\dot{e}_{0}$ and $\sigma_{0}$ are material constants. At low stresses this equation becomes

$$
\dot{e}=\dot{e}_{0}\left(\frac{\sigma}{\sigma_{0}}\right) \text {. }
$$

This suggests that at low stresses the material behaves like a Newtonian fluid. At high stresses, however, the expression may be shown to exist in the form

$$
\dot{e}=\left(\frac{\dot{e}_{0}}{2}\right) \exp \left(\frac{\sigma}{\sigma_{0}}\right)
$$

or

$$
\log \dot{e}=K\left(\frac{\sigma}{\sigma_{0}}\right)+k .
$$

The data were plotted on semilog paper and reproduced in figure 10 . The curves at $300^{\circ} \mathrm{F}$ indicate an approach to linearity as the time at stress is increased. At $900^{\circ} \mathrm{F}$, the shape of the curves indicates that the flow mechanisms, although temperature-sensitive, are less affected by the time at which the creep rate was measured for any stress value employed. The positions of the curves, however, indicate that the short-time ( 5 to $20 \mathrm{~min}$ ) strain hardening occurring at $700^{\circ} \mathrm{F}$ is equal to or greater than that occurring at $300^{\circ} \mathrm{F}$. This phenomenon is in agreement with another prediction of the theory of the effect of solute atoms as proposed by Cottrell [14]. In the short-time tensile tests of this alloy [7], the magnitude of the serrations in the stress-strain curve attained a maximum in the temperature range $600^{\circ}$ to $800^{\circ} \mathrm{F}$.

\section{d. Second Stage of Creep}

It was previously pointed out in Andrade's creep equation [15] that one of the components described a steady state of flow. This would indieate that when $B=0$,

or

$$
l=l_{0} e^{K t}
$$

$$
\frac{1}{l} \frac{d l}{d t}=K
$$

The region to which this formula applies is generally called the second stage of creep. The apparent balance between the competing mechanisms of strain hardening and recovery of metals during this stage has caused a number of theories to be proposed to describe this steady state. Generally, the analyses of the relations between stress, temperature, and second stage creep rate are based on Eyring's chemical-rate theory [18] or are a result of curve fitting.

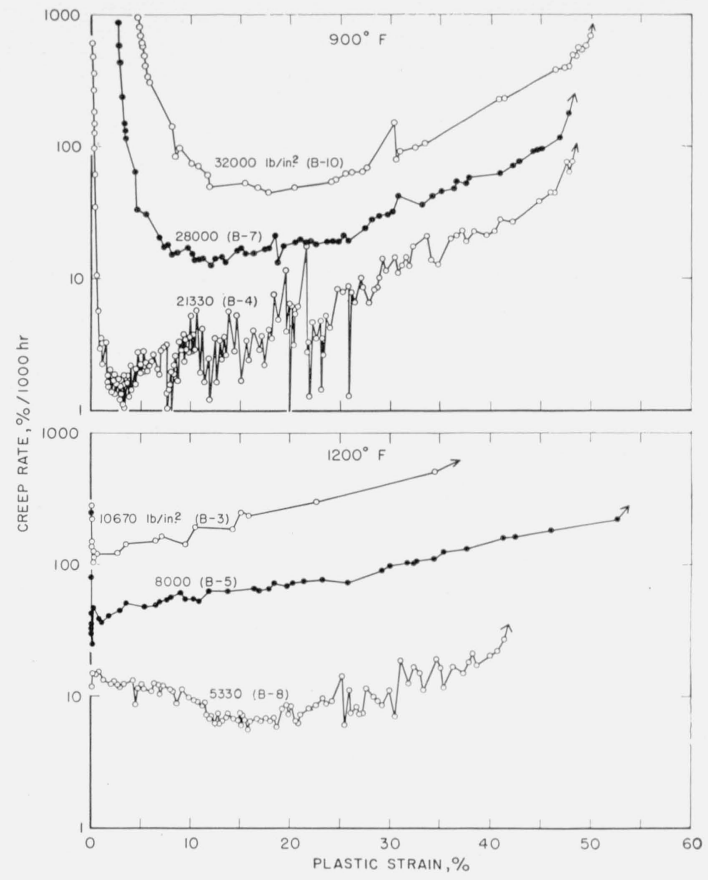

Figure 5. Creep rate-strain characteristics of $7_{0}$ percent $\mathrm{Ni}-30$-percent-Cu alloy at $900^{\circ}$ and $1,200^{\circ} \mathrm{F}$. Specimen numbers correspond to those found in the tables.

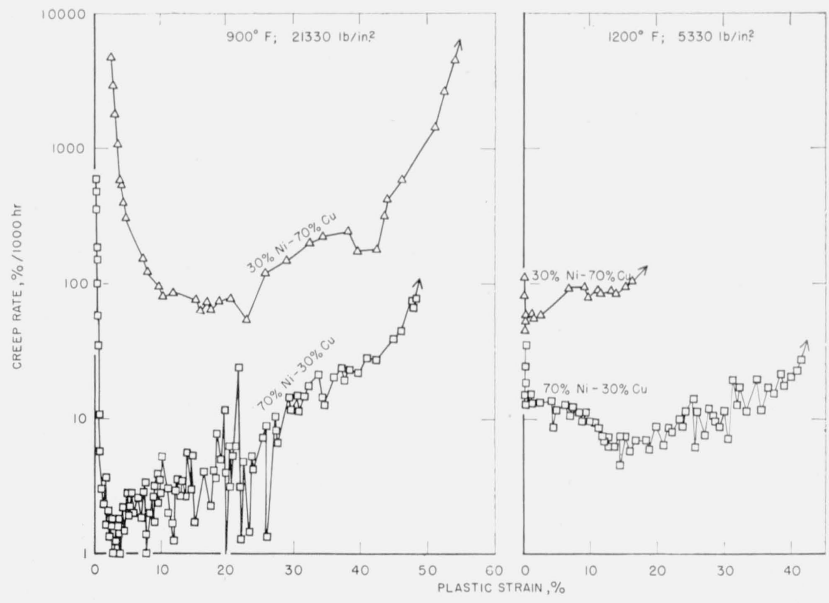

Figure 6. Creep rate-strain relations for specimens of two nickel-copper alloys tested at $900^{\circ}$ or $1,200^{\circ} \mathrm{F}$.

Essential features of each of these proposals have been incorporated into a logarithmic rate law in which the second stage creep rate is considered to be proportional to a power function of the stress. The relations between stress and creep rate of the specimens used in the present investigation are shown in figures 11 and 12 . At $300^{\circ}, 700^{\circ}$, and $900^{\circ} \mathrm{F}$ the curves for the alloys are at higher stress levels than those for the component metals although at $300^{\circ} \mathrm{F}$ the creep strength of the nickel was only slightly 

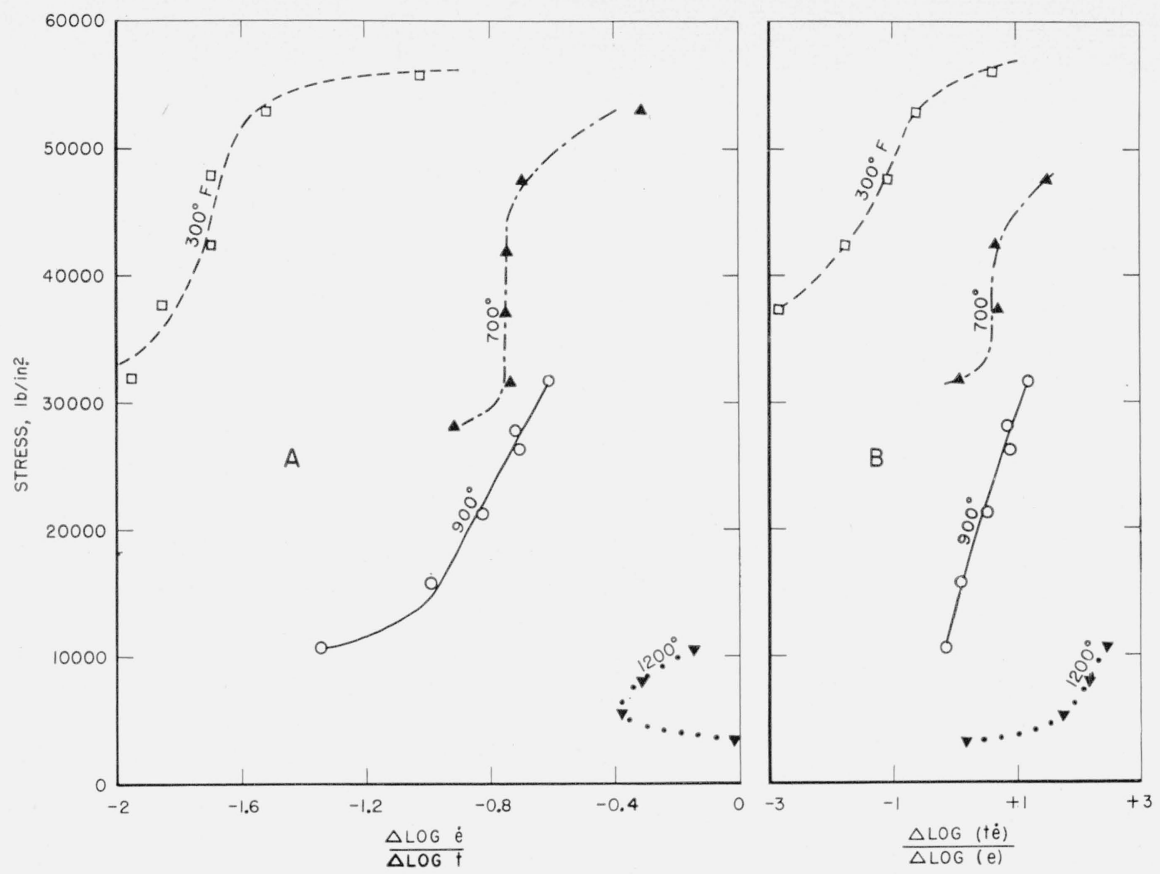

FigURE 7. Relations of stress to the slopes of the log creep rate-log time curves and of the log product of time and creep rate-log strain curves during the first stage of creep of 70 -percent-Ni-30-percent-Cu specimens at different temperatures.
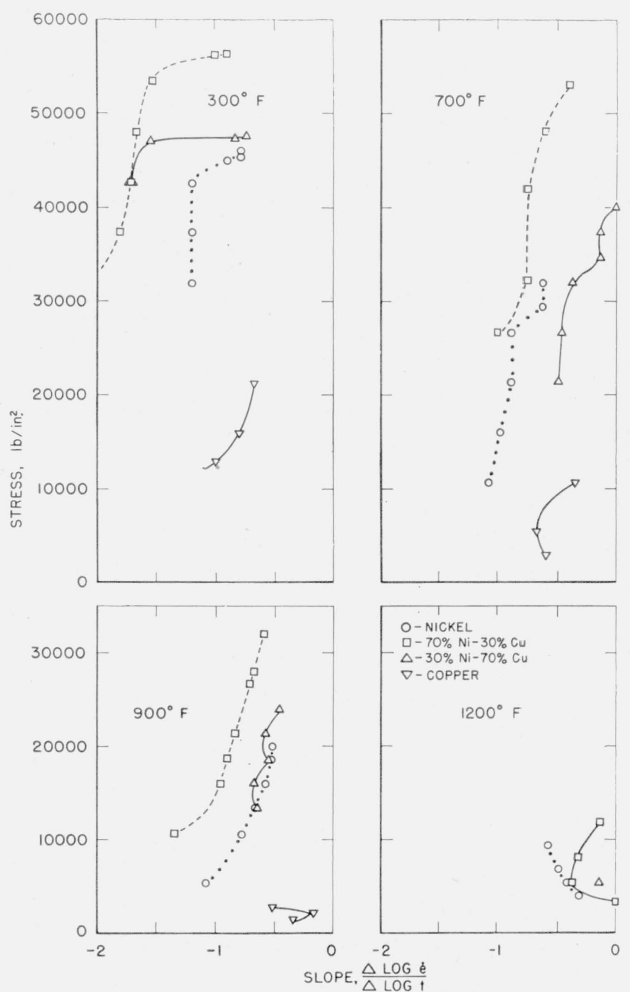

FIGURE 8. Relation of stress to the slopes of the log creep rate-log time curves during first stage of creep at different temperatures.

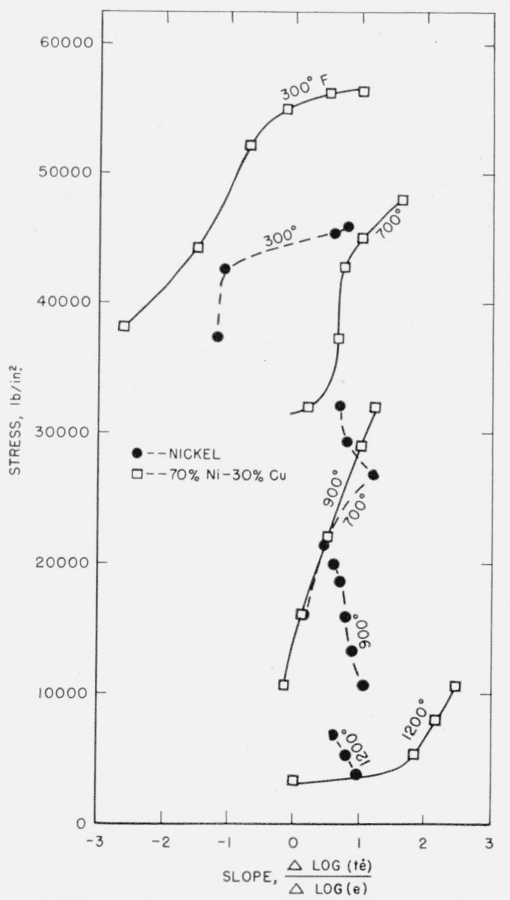

FIgure 9. Relation of stress to the slopes of the log product of the time and creep rate-log strain curves during the first stage of creep. 


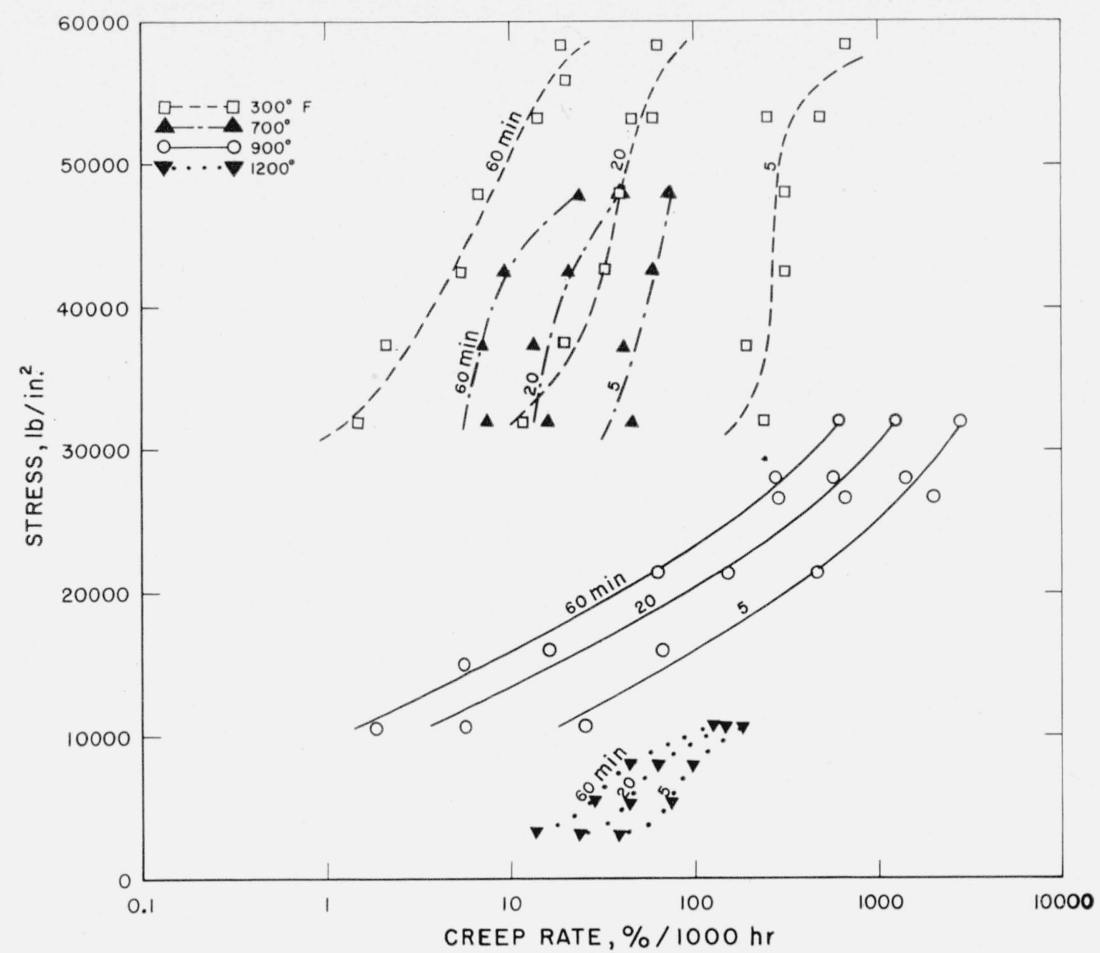

FIGURE 10. Relation of stress to first stage creep rate of 70 -percent-Ni-30-percent-Cu alloy at different temperatures and times.

less than that of the 30-percent-Ni-70-percent-Cu alloy. Thus, the strengthening effects due to alloying that was observed in the first stage are still evident during the second stage of creep. At $1,200^{\circ}$ $\mathrm{F}$, however, the nickel specimens appeared stronger than those of the 30-percent-Ni-70-percent-Cu alloy, indicating that factors affecting the strengths at low temperatures are not necessarily as effective at the higher test temperatures. Similar strengthening effects were obtained previously in short-time tensile tests on high-purity and commercial grades of the 70-percent-Ni-30-percent-Cu alloy [6]. Above the threshold stresses at which creep begins at $300^{\circ} \mathrm{F}$ (fig. 11), small changes in stress caused a marked change in creep rate. However, the relatively high threshold stresses at $300^{\circ}$ may be attributed to a combination of a high degree of strain hardening and aging accompanied by a low rate of recovery. As the temperature is raised, (figs. 11 and 12) recovery predominates and the threshold stresses needed to produce equal second stage rates become less.

The relations between temperature and stress necessary to produce different second-stage creep rates are shown for the 70-percent-Ni-30-percent-Cu alloy in figure 13. As the shape of this family of curves is typical of the behavior of all the metals used in this investigation, the data for the other metals are not shown. However, the short-time tensile strengths of the 70-percent-Ni-30-percent$\mathrm{Cu}$ alloy are included for comparison. In the temperature range $300^{\circ}$ to $700^{\circ} \mathrm{F}$, the rate of change in stress with temperature increases with increasing creep rates; whereas, the reverse is true in the $900^{\circ}$ to $1,200^{\circ} \mathrm{F}$ range. However, within the $700^{\circ}$ to $900^{\circ} \mathrm{F}$ range, these slopes appear to be independent of creep rate. Apparently, both high- and lowtemperature mechanisms are active within this latter range of temperatures.

The relation between stress and nickel content to produce various second-stage creep rates at different temperatures is shown in figures 14 and 15 . In general, the slopes of the stress-nickel content curves to produce second-stage creep rates of 0.5 percent, 1 percent, 10 percent, or 100 percent per $1,000 \mathrm{hr}$ are a maximum as the nickel content is increased from zero to 30 percent. It is observed that the variation of stress with nickel content at any creep rate is generally greater at $700^{\circ} \mathrm{F}$ than at other test temperatures. Several phenomena are considered to be responsible for the latter observation. Of the temperatures used, simultaneous straining and recrystallization of copper have been reported at $700^{\circ} \mathrm{F}$ [7]; this temperature is within the vicinity of the Curie point of nickel [3]; serrated stress-strain curves are obtained for specimens of the alloys in short-time tensile tests [7].

The relation between stress and nickel content to produce different creep rates at different temperatures is shown in figure 15. Although the 70-percentnickel alloy specimens showed the best creep resistance at all temperatures and stresses, the parallelism of some of the line segments indicated that the strengthening effects of nickel were practically independent of the second-stage creep rate. 


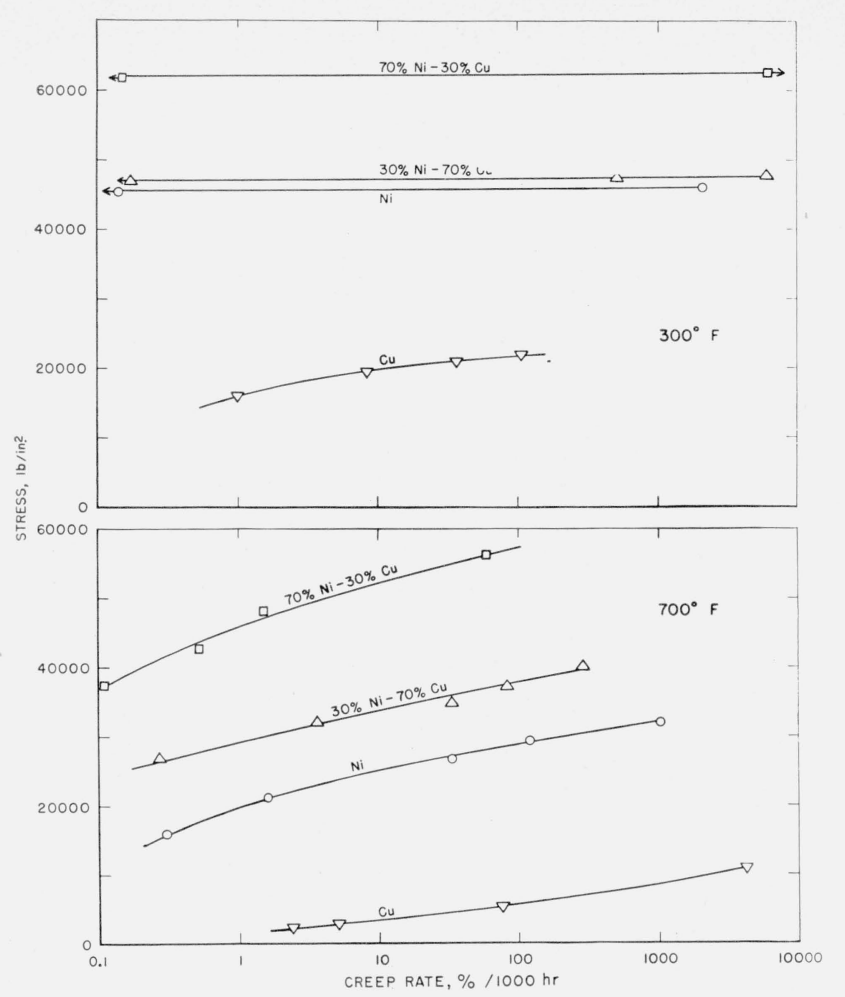

Figure 11. Influence of stress on the average creep rate during the second stage at $300^{\circ}$ and $700^{\circ} \mathrm{F}$.

\section{1}

Larson and Miller [19] have proposed time-temperature relationships for describing creep behavior and rupture strength. For any given stress

or

$$
T_{R}(20+\log t)=K
$$

$$
T_{R}(20-\log r)=C
$$

where $T_{R}=$ temperature in degrees Rankine, $t=$ fracture time in hours, $r=$ second-stage creep rate in percent per $1,000 \mathrm{hr}$ and $C$ and $K$ are constants. Also if the logarithm of the stress is plotted against $C$ or $K$, all values for specimens of each material should fall on a single curve in the absence of major structural changes. Conformance to these predictions is obtained for the materials used in this investigation as shown in figure 16 . The discontinuous curves for copper are attributed, in part, to recrystallization and extensive grain growth during creep. Moreover, the relative positions of the nickel and the 30-percent nickel alloy indicate the factors contributing to the strengthening of the nickel due to alloying are most effective within the parameter values of 16 to $26 \times 10^{3}$.

\section{e. Creep Rate-Ductility Relations}

One of the most important structure-sensitive properties of metals is ductility. Previous investigations have shown that no consistent trend existed between ductility values and the rate of straining at different
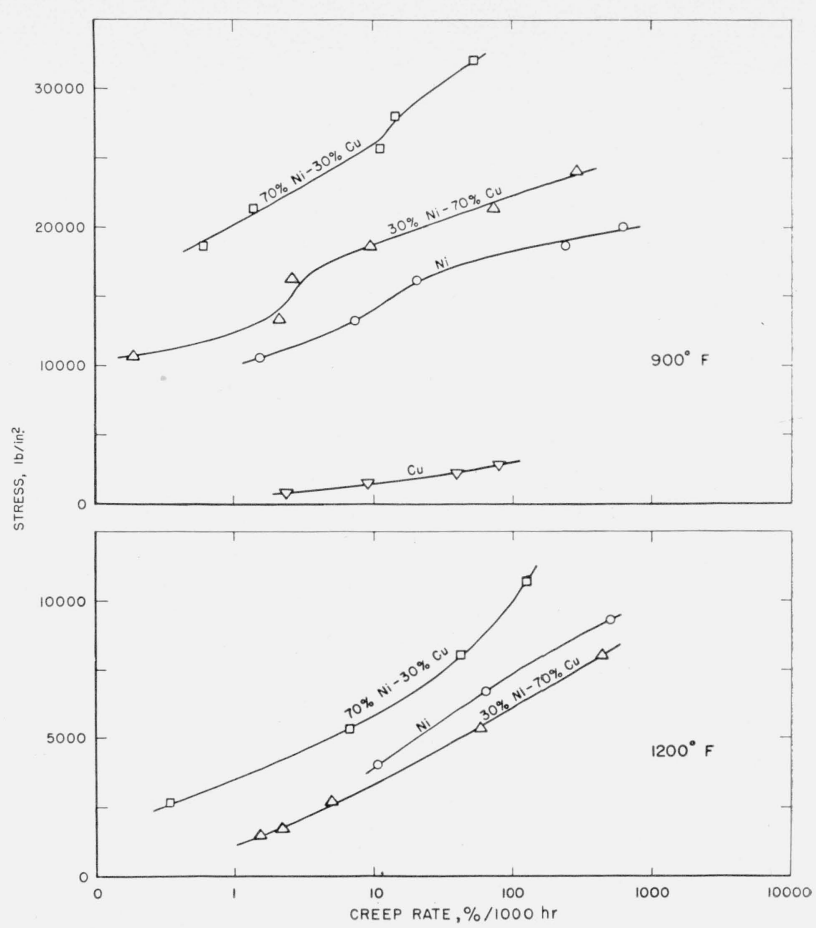

FIGURE 12. Influence of stress on the average rreop rate during the second stage at $900^{\circ}$ and $1,200^{\circ} \mathrm{F}$.

temperatures. Therefore, predictions of ductility values, based on fundamental concepts, does not appear possible at this time. However, it is generally conceded that the ductility of metals depends on the initial concentration of lattice defects and the formation and motion of new defects throughout the crystals. Apparently, as observed in short-time tensile tests on materials of the nickel-copper system [7], substantial changes in the ductility-temperature relations are made by alloying. Changes of this type have been analyzed by Cottrell [14] who considered them to be related to the creation of vacancies and interstitial defects during cold-working.

The relation between strain values, obtained one hour after application of load and the logarithm of the second-stage creep rates for specimens tested at $700^{\circ}, 900^{\circ}$, and $1,200^{\circ} \mathrm{F}$ is shown in figure 17 . Sufficient data were not available for analyzing the behavior of the specimens at $300^{\circ} \mathrm{F}$. The initial strain values, corresponding to equal second-stage creep rates at $700^{\circ}$ and at $900^{\circ} \mathrm{F}$, increase as the copper content of the specimens is decreased from 100 to 30 percent. The strain values at $700^{\circ} \mathrm{F}$ for the nickel are approximately the same as those of the 30-percent-Ni-70-percent-Cu alloy; whereas, at $900^{\circ} \mathrm{F}$ the corresponding strain values for the nickel are greater than those of the 30-percent-nickel alloy. Moreover at $1,200^{\circ} \mathrm{F}$, the strain values of the nickel are higher than those for either of the alloys. These observations indicate that the flow characteristics of these metals are strongly dependent on the copper content. 


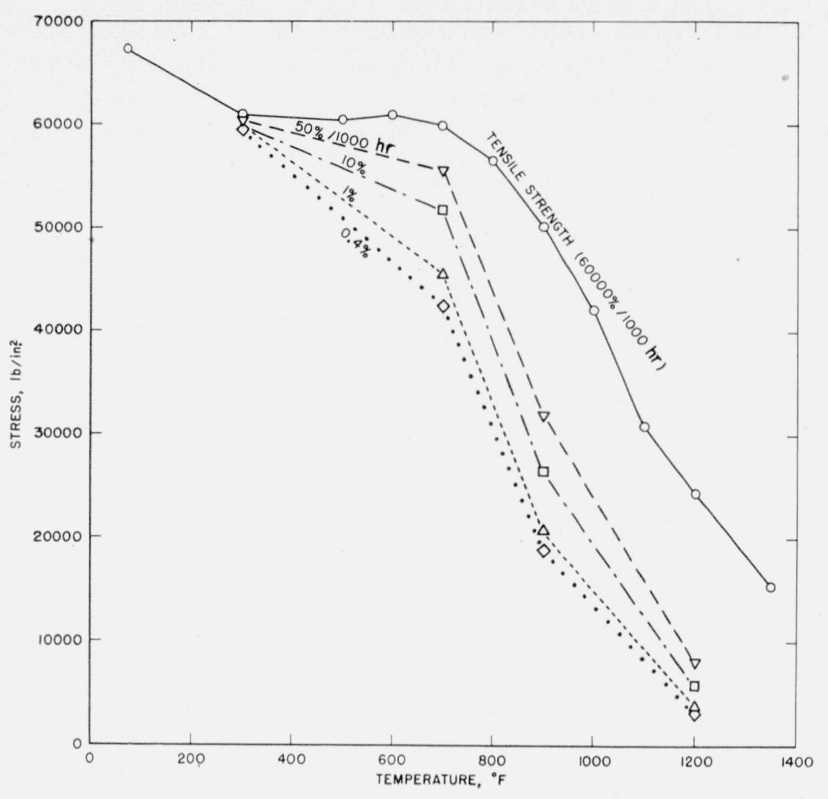

Figure 13. Variation of stress with temperature required to produce various second-stage rates of $\% 0$-percent- $\mathrm{Ni}$-30-percent$\mathrm{Cu}$ alloy.

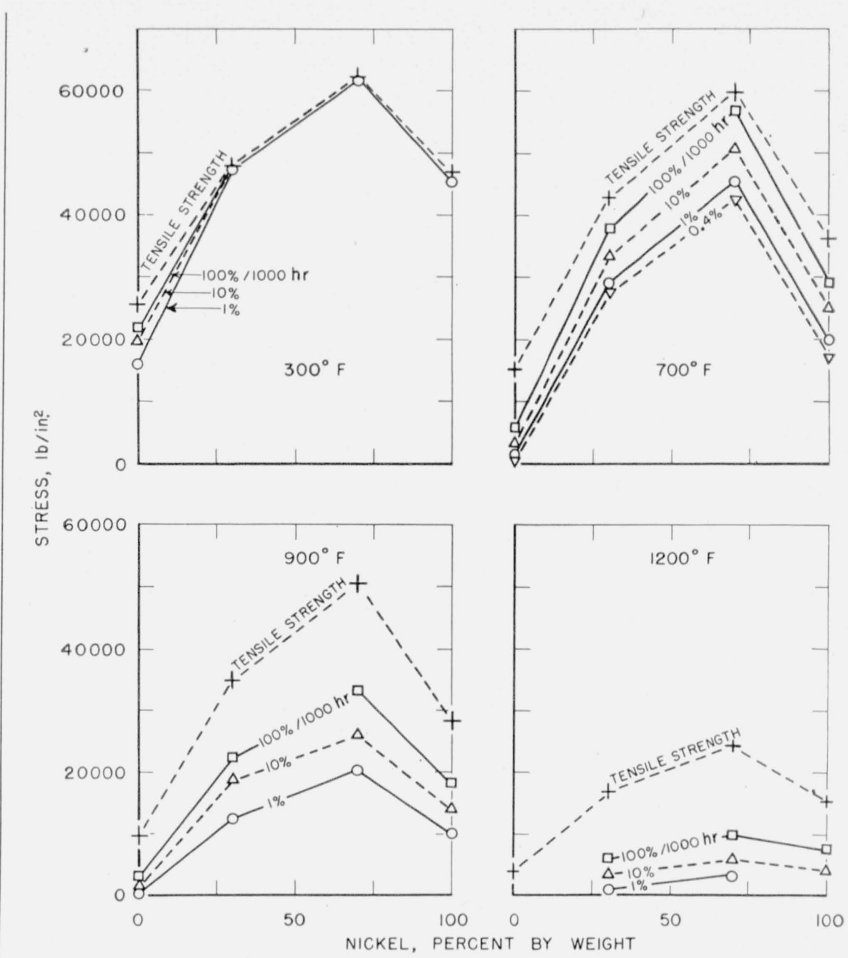

FiguRE 15. Variation of stress with nickel content to produce different second-stage creep rates at various temperatures.
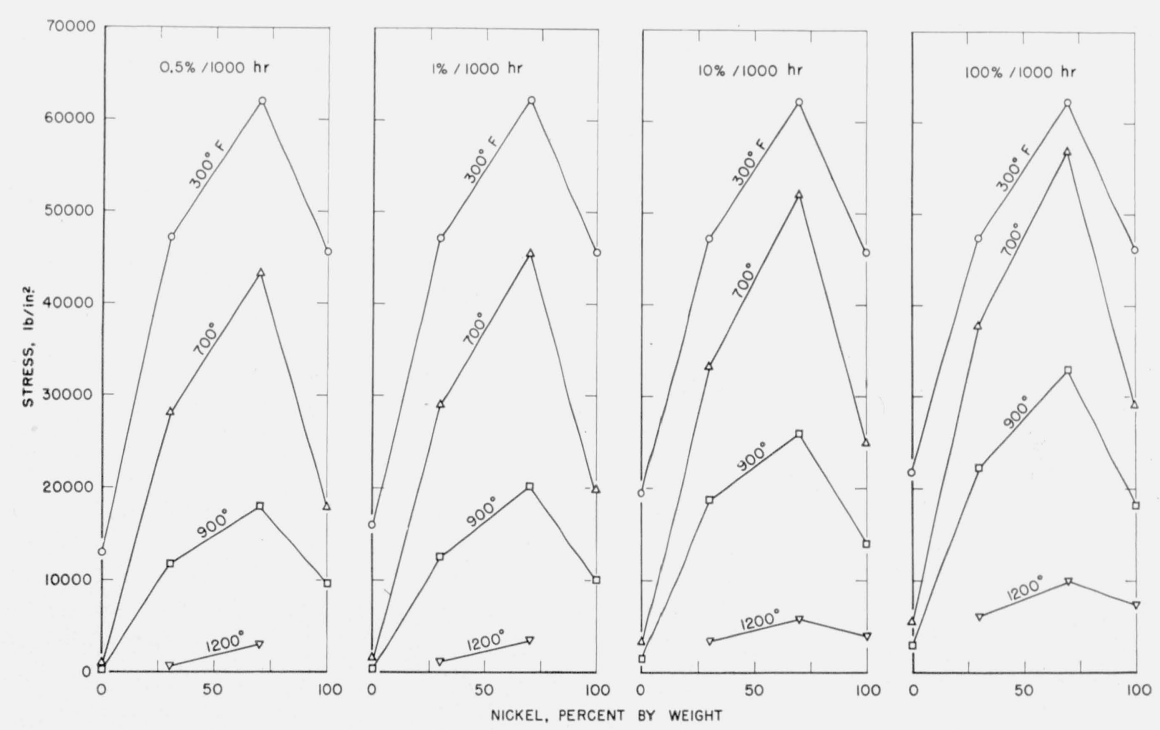

FIGURE 14. Variation of stress with nickel content to produce equal second-stage creep rates at different temperatures. 


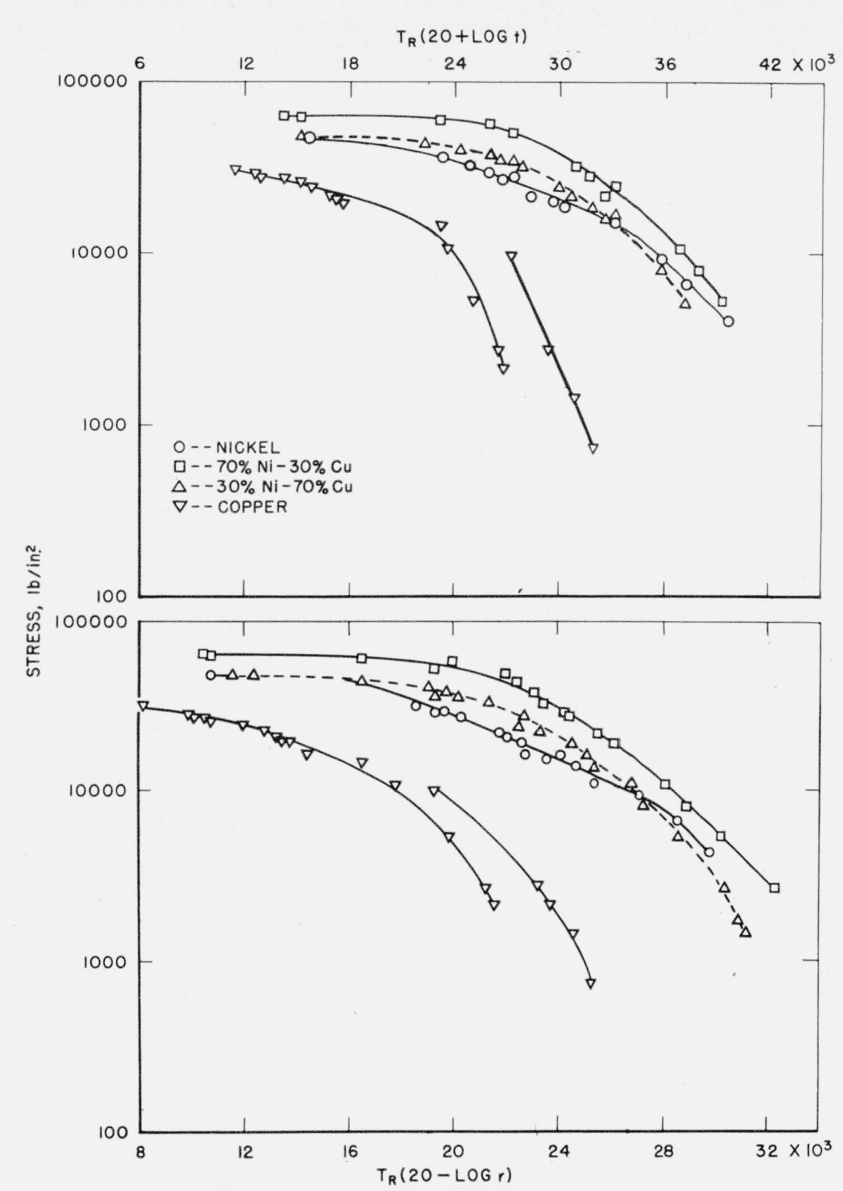

Figure 16. Relation between creep stress and fracture time or creep-rate parameters.

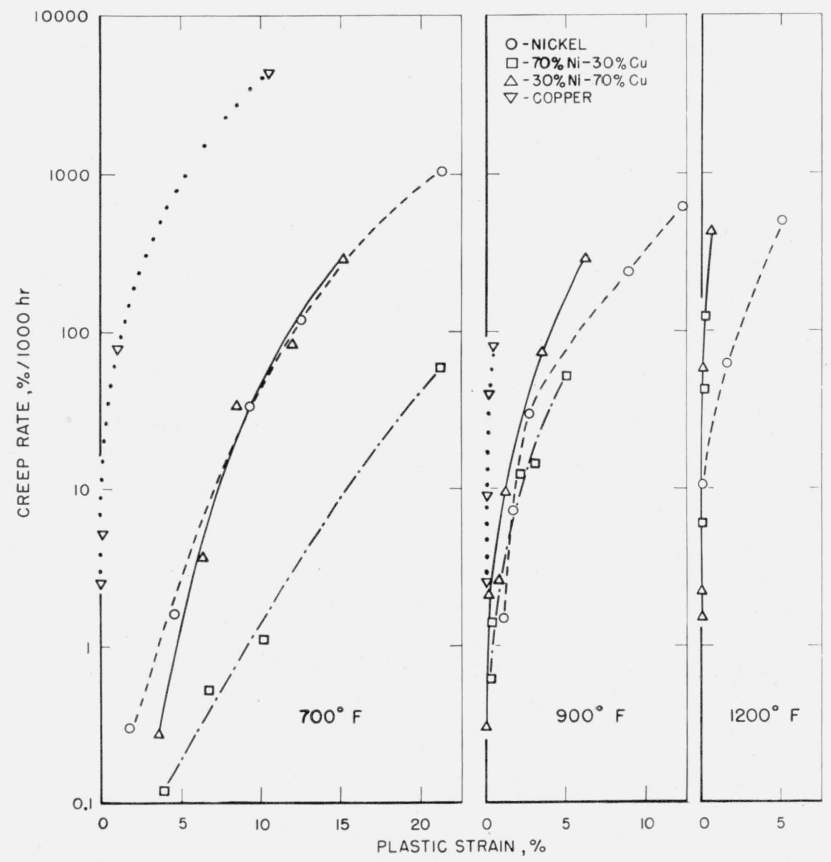

FIGURE 17. Relation of strain, measured $1 \mathrm{hr}$ after application of load, to the second-stage creep rate at different temperatures.
The relation between second-stage creep rate and elongation or reduction of area values for specimens tested to complete fracture at $700^{\circ}, 900^{\circ}$, and $1,200^{\circ}$ $\mathrm{F}$ is shown in figure 18 . It is noteworthy that the ductility of the specimens of the alloys was intermediate between the low values for copper and the high values of the nickel.

\section{f. Third Stage of Creep, Specimen Contour, and Post-Test}

Hardness

Several processes are discussed in the literature as being the causes of the initiation and the propagation of accelerating creep in the third stage. Among these processes are the following: rising stresses resulting from a decrease in cross-sectional area of the specimen, structural changes, extensive recovery or recrystallization, and nucleation and density of void nuclei. Machlin [20] has recently developed a theory based on the probability of the growth of preexistent voids by vacancy condensation. Each of the above concepts are applicable to a limited extent to the data for the present investigation. No local contraction (necking) nor voids of a microscopic size were observed for any of the specimens that were examined after stopping the tests prior to the third stage. Therefore, it is concluded that the necking and the growth of cracks, were a consequence of accelerating creep in the third stage. Similar observations were made previously for the copper [1] and for the nickel [5]. With the exception of nickel, previously discussed [5], the degree of necking, in general, decreased with increase in temperature and with decrease in creep rate. This typical behavior is illustrated by the curves shown for the 70-percent$\mathrm{Ni}-30$-percent-Cu alloy specimens in figure 19. A. Moreover, the specimens exhibiting the greatest tendency to contract locally (B-18 and B-13) both showed a tendency toward an increase in hardness with increase in contraction of area values (fig. 19B).

For the specimens tested at $1,200^{\circ} \mathrm{F}(\mathrm{B}-3, \mathrm{~B}-5$ and B-8), the opposite effect on hardness was observed. The tendency to soften as the contraction of area values increased was attributed both to the relatively high temperature and decrease in creep rate. This behavior was accompanied by a progressively increasing number of microscopic cracks both near the surface and in the interior of the specimens.

The relations between maximum post-test hardness and second-stage creep rate are shown in figure 20 for specimens of the nickel and the two alloys. The general trends were for the hardness to increase with a decrease in test temperature (creep rate constant) or with increase in creep rate (temperature constant). This same observation was made for the copper; however, the hardness values were too low to be included in the figure. Alloying the copper tended to raise the hardness values markedly; however, with one exception the maximum hardness value for the nickel was higher than the corresponding values of the 30-percent-Ni-70-percent-Cu alloy.

Apparently, some of these and previous data are consistent with the observations on the lattice param- 

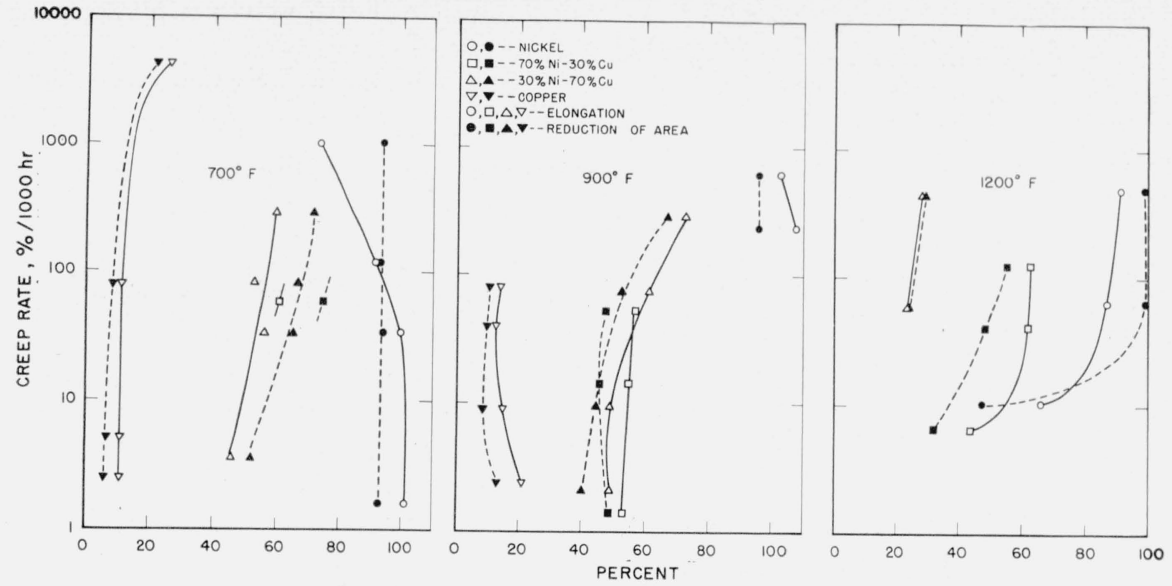

Figure 18. Effect of second-stage creep rate on elongation or reduction of area.
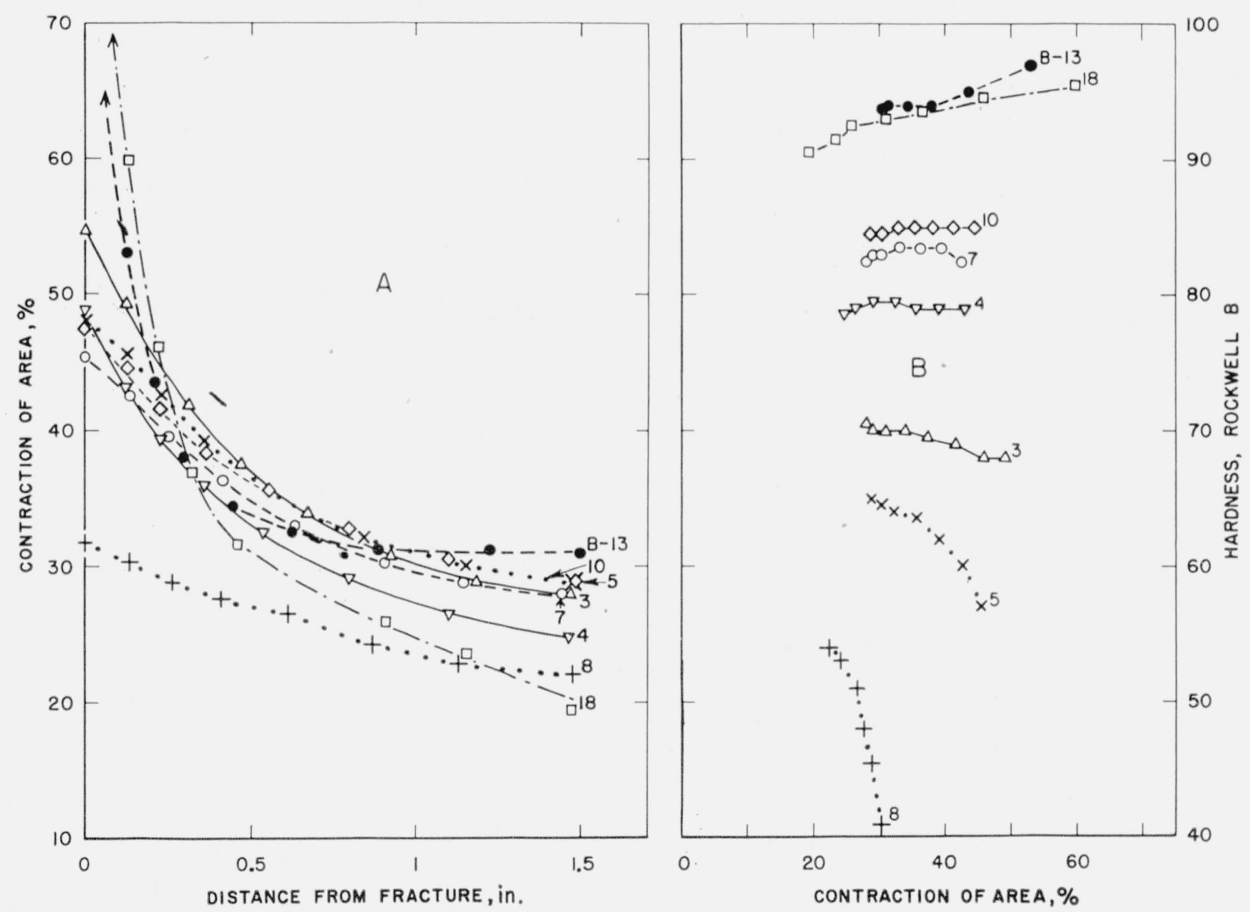

FIGURE 19. Specimen contours and hardness distributions of specimens of 70-percent-Ni-30-percent-Cu alloy tested to complete fracture

\begin{tabular}{|c|c|c|}
\hline $\begin{array}{c}\text { Specimen } \\
\text { number }\end{array}$ & $\begin{array}{c}\text { Tempera- } \\
\text { ture }\end{array}$ & $\begin{array}{c}\text { A verage } \\
\text { creep rate, } \\
\text { second stage }\end{array}$ \\
\cline { 1 - 1 } & $\circ F$ & $\% / 1,000 h r$ \\
B-18 & 300 & 220,000 \\
B-13 & 700 & 59 \\
B-10 & 900 & 51.8 \\
B-7 & 900 & 14.3 \\
B- 4 & 900 & 1.4 \\
B-3 & 1,200 & 125 \\
B- 5 & 1,200 & 41 \\
B- 8 & 1,200 & 6.6 \\
& & \\
\hline
\end{tabular}




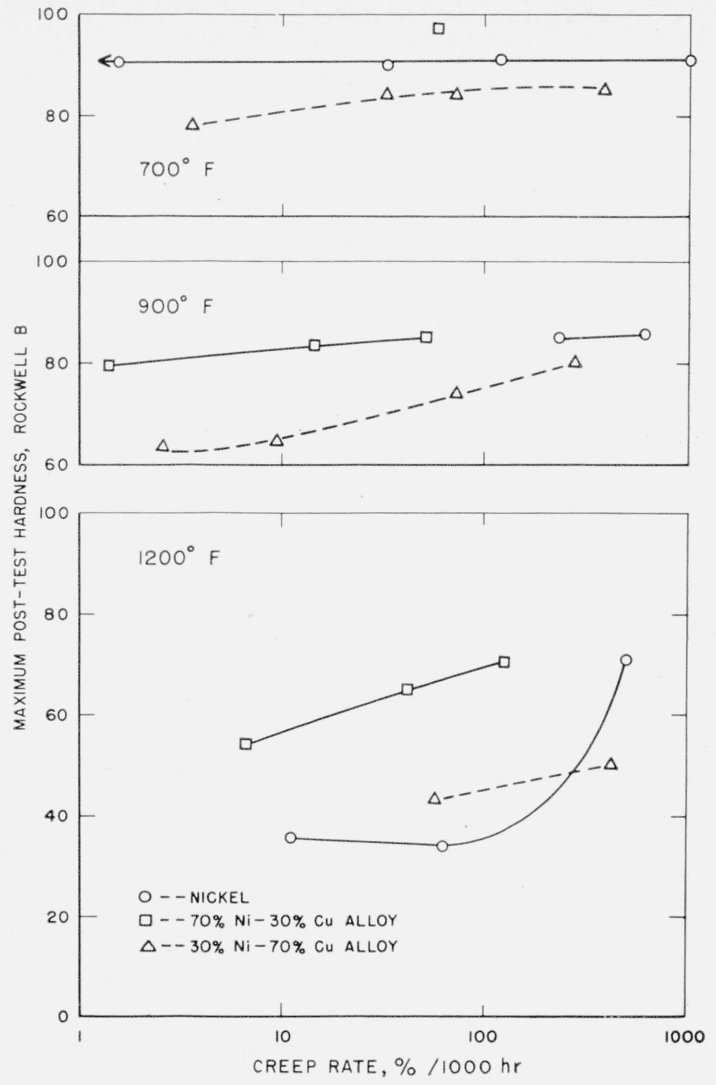

Figure 20. Effect of second-stage creep rate on the maximum post-test hardness values of specimens tested to complete fracture at different temperatures.

eters of the copper-nickel system recently presented by Coles [21].

\section{g. Activation Energy}

Determinations of activation energies from data obtained in creep tests on different metals have been made in recent years. Some investigators have found that the activiation energy associated with creep is approximately equal to that for self-diffusion of the material. Other data depart rather markedly from this observation. Also controversial are the influences of prior-strain history, strain, temperature, grain and subgrain sizes, and the metallurgical changes occurring during creep. In addition, differences in values of activation energy may be attributed to the use of different basic assumptions in the calculations. For example, the activation energy for creep of the nickel used in this investigation was calculated as about 53,500 calories per mole according to the analysis of Manjoine and Mudge [23] and about 65,000 calories per mole by using the dislocation climb mechanism proposed by Weertman and Shahinian [22]. It was, therefore, thought unfruitful to pursue further any analysis of activation energy until a more complete appraisal of the basic factors affecting the calculations can be made.

\subsection{Effect of Prior-Strain History on Creep Behavior}

\section{a. Strain-Time and Stress-Strain Curves}

An analysis of experimental data led Ludwik [24] to propose that the strain-hardening characteristics of a material were a function of the instantaneous strain, strain rate, and temperature and were practically independent of the prior strain history. Many fundamental data have since been accumulated to test the validity of this equation of state. It is now the generally accepted view that this relation is generally invalid and that the data tending to confirm this and similar proposals may be considered as only special cases of the general problem of plastic flow.

Wood [25], in summarizing the factors affecting the structural changes in metals during deformation, indicated that the parent grains are fragmented. The size of the substructures so formed increases with increase in test temperature and with decrease in rate of straining. The boundaries of the substructures can act as barriers to the motion of dislocations or as sites where stable barriers form. During a constant-stress creep test the substructure tended toward an equilibrium size characteristic of the stress and test temperature. Systematic changes in subgrain size, accompanied by changes in resistance to deformation, was predicted for specimens as the test temperature or strain rate was altered. A quantitative test of this hypothesis was recently made by Hazlett and Hansen [10] who indicated that the shape of the creep curve could be materially altered by changes in the initial substructure of the base material and further altered by alloying. The prestraining of the nickel in that investigation was done exclusively at room temperature and followed by a recovery treatment at $1,290^{\circ} \mathrm{F}$.

The influence of prior straining in creep on the subsequent creep behavior at elevated temperature and tensile properties at room temperature of nickel and copper has been discussed in previous publications $[1,2,3,5]$. The present paper is concerned with similar effects on the 70-percent-Ni-30-percent$\mathrm{Cu}$ and 30-percent-Ni-70-percent-Cu alloys. The test conditions and results are summarized in tables 5 and 6 and analyzed graphically in figures 21 to 27 , inclusively.

The effect of the magnitude of the initial stress and the subsequent rate of loading on the creep behavior of specimens of 70-percent-Ni-30-percent-Cu alloy at $300^{\circ} \mathrm{F}$ is shown in figure 21 . If the only modes of deformation, existing for these specimens, were the ones suggested by Wood [25], then the curves for specimens tested at equal stresses should merge after a time. Apparently, an aging phenomenon, such as was shown for nickel [5] existed for this alloy under these test conditions. Although the reduction of area values are approximately independent of the rate of loading, elongation and the true stress at fracture appear to be dependent on this factor.

The influence of alloying the nickel with copper on the resistance to creep at $300^{\circ} \mathrm{F}$ of slowly loaded specimens can be deduced from a comparison of the difference in stresses, in excess of the tensile strengths, 


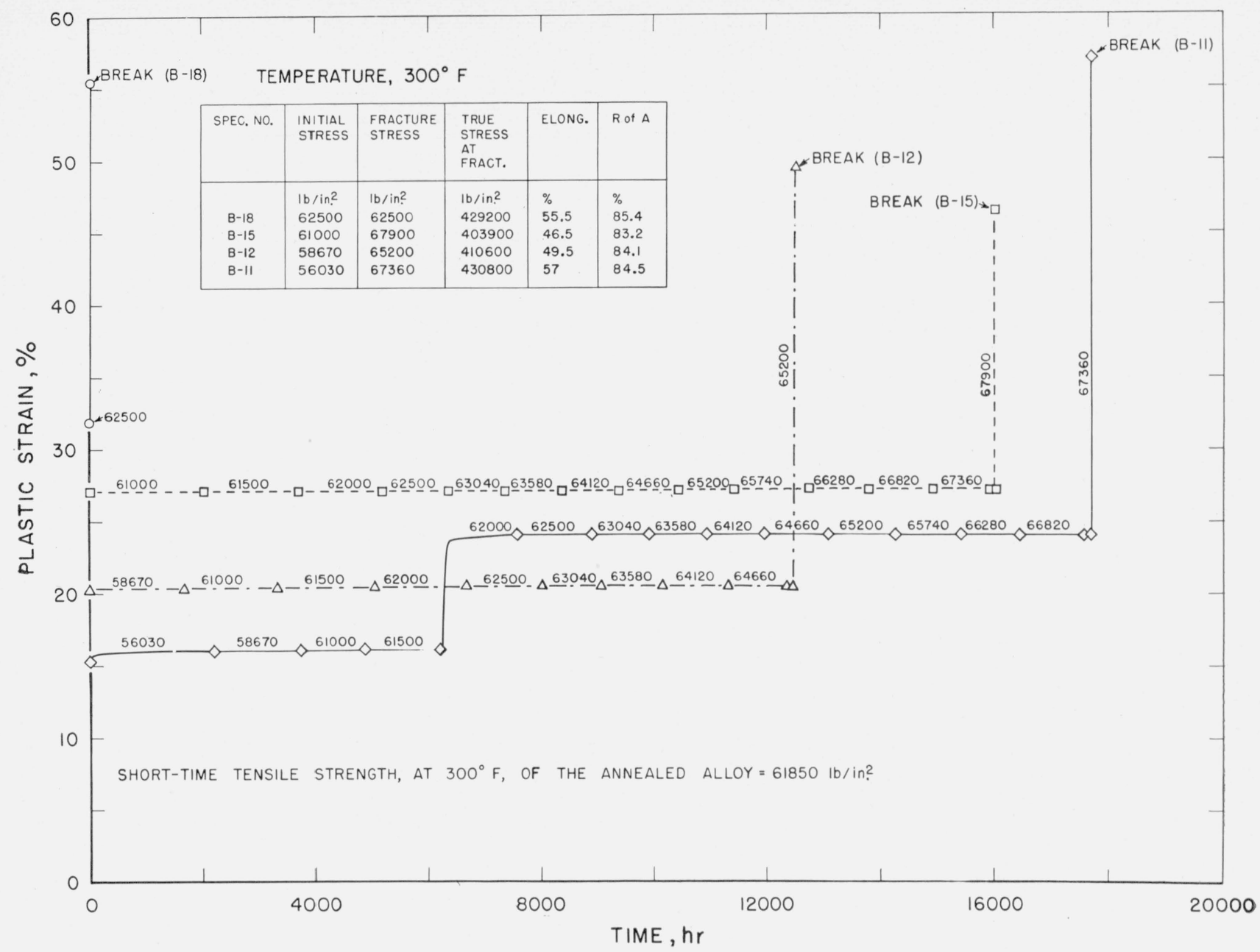

Figure 21. Effect of rate of loading at $300^{\circ} \mathrm{F}$ on the strain-time characteristics of 70 -percent-Ni-30-percent-Cu alloy.

required to produce fracture in $1,000 \mathrm{hr}$. The 70 percent-Ni-30-percent-Cu alloy required a stress at least $3,350 \mathrm{lb} / \mathrm{in}^{2}$ in excess of its short time tensile strength (fig. 21) whereas the nickel required only $1,600 \mathrm{lb} / \mathrm{in}^{2}{ }^{2}$ or less, in excess of its tensile strength to produce complete fracture in 1,000 hours in slowly loaded specimens [5]; the short-time tensile strengths at $300^{\circ} \mathrm{F}$ of the alloy and nickel were 61,850 and $46,400 \mathrm{lb} /$ in. $^{2}$, respectively. This increase in creep strengths at $300^{\circ} \mathrm{F}$ of both the alloy and the nickel is primarily attributed to a combination of strainaging and strain-hardening characteristics. The results show that the strain aging and hardening are much more prominent in the specimen loaded slowly than in the specimens loaded rapidly to the selected creep stresses.

The strain-aging characteristics at $300^{\circ} \mathrm{F}$ of the alloy are further illustrated, in figure 22 , by a comparison of the relative positions of the stress-strain curves associated with the slowly loaded specimens (dashed curves) and the specimens loaded at 5,330 $\mathrm{lb} / \mathrm{in}^{2} \mathrm{hr}$ (solid curve). In the absence of strain aging, the curves for the four specimens should coincide.
The effect of straining a 70-percent-Ni-30-percent$\mathrm{Cu}$ specimen at a lower stress at $900^{\circ} \mathrm{F}$ on the subsequent creep behavior at a higher stress and at the same temperature, is shown in figure 23. Although the second stage creep rate was approximately the same for the specimen (B-14) prestrained 2.23 percent at $18,670 \mathrm{lb} / \mathrm{in}^{2}{ }^{2}$ as that for the specimen (B-4) not prestrained, the behavior of the two specimens in the first stage was somewhat different. The duration of the first stage of the former specimen was relatively short in comparison with that of the latter. These observations are consistent with Wood's theory describing the tendency of the subgrains to approach an equilibrium size. The fact that this behavior is not typical at $900{ }^{\circ} \mathrm{F}$ is shown by the results reproduced in figure 24. The specimens were prestrained different amounts at temperatures of $300^{\circ}, 700^{\circ}$, $900^{\circ}$, or $1,200^{\circ} \mathrm{F}$. The specimens prestrained at $300^{\circ}, 700^{\circ}$, and $1,200^{\circ} \mathrm{F}$ showed a tendency toward an increase in second stage creep rate and a decrease in fracture time when compared to the specimen loaded at the standard rate and strained at $900^{\circ} \mathrm{F}$. Straining slowly at $900^{\circ} \mathrm{F}(\mathrm{B}-14)$ to a value of 5 percent tended to decrease the second stage creep 


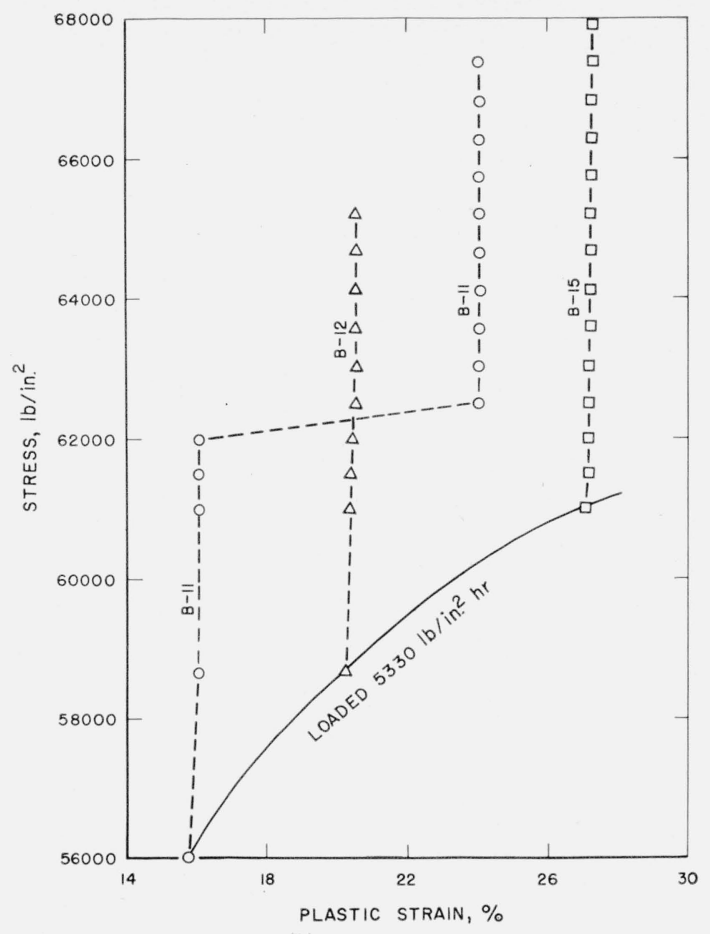

Figure 22. Effect of rate of loading at $300^{\circ} F$ on the stressstrain relations of 70 -percent- $\mathrm{Ni}-30$-percent-Cu alloy.

For rate of loading schedule, see figure 21.

rate and increase the fracture time and elongation. The strain associated with the first stage of creep increased as the prestraining temperature was increased. Moreover, the first stage was practically eliminated for the specimens prestrained relatively large amounts at $300^{\circ}$ or $700^{\circ} \mathrm{F}$ (B-17 and B-9).

The effect of prestraining at $900^{\circ} \mathrm{F}$ on the creep characteristics at $1,200^{\circ} \mathrm{F}$ of the 70 -percent-Ni-30percent-Cu alloy is shown in figure 25. Prestraining caused a detectable first stage, a decrease in secondstage creep rate, elongation, and fracture time at $1,200^{\circ} \mathrm{F}$.

The influence of prestraining temperature and the amount of prestrain on the creep characteristics of The 30-percent-Ni-70-percent-Cu alloy tested at $900^{\circ} \mathrm{F}$ with a stress of $18,670 \mathrm{lb} / \mathrm{in}^{2}{ }^{2}$ is shown in figure 26. Compared to the reference specimen (C-8) the fracture time was decreased and the second-stage creep rate increased for all the prestrained specimens. The maximum increase in creep rate was observed for the specimen (C-13) prestrained at $1,200^{\circ} \mathrm{F}$ to 10.22 percent whereas the minimum increase was observed for the specimen (C-21) prestrained at $900^{\circ} \mathrm{F}$ to a small strain value. Apparently, the substructures developed in the latter specimen had only a slight effect on the second-stage rate, but caused a marked decrease in fracture time and elongation. Generally, for the specimens of 30 -percent-Ni-70-percent-Cu an increase in the prestraining temperature (amount of prestrain constant) was accompanied by an increase in secondstage creep rate and a decrease in values of elongation

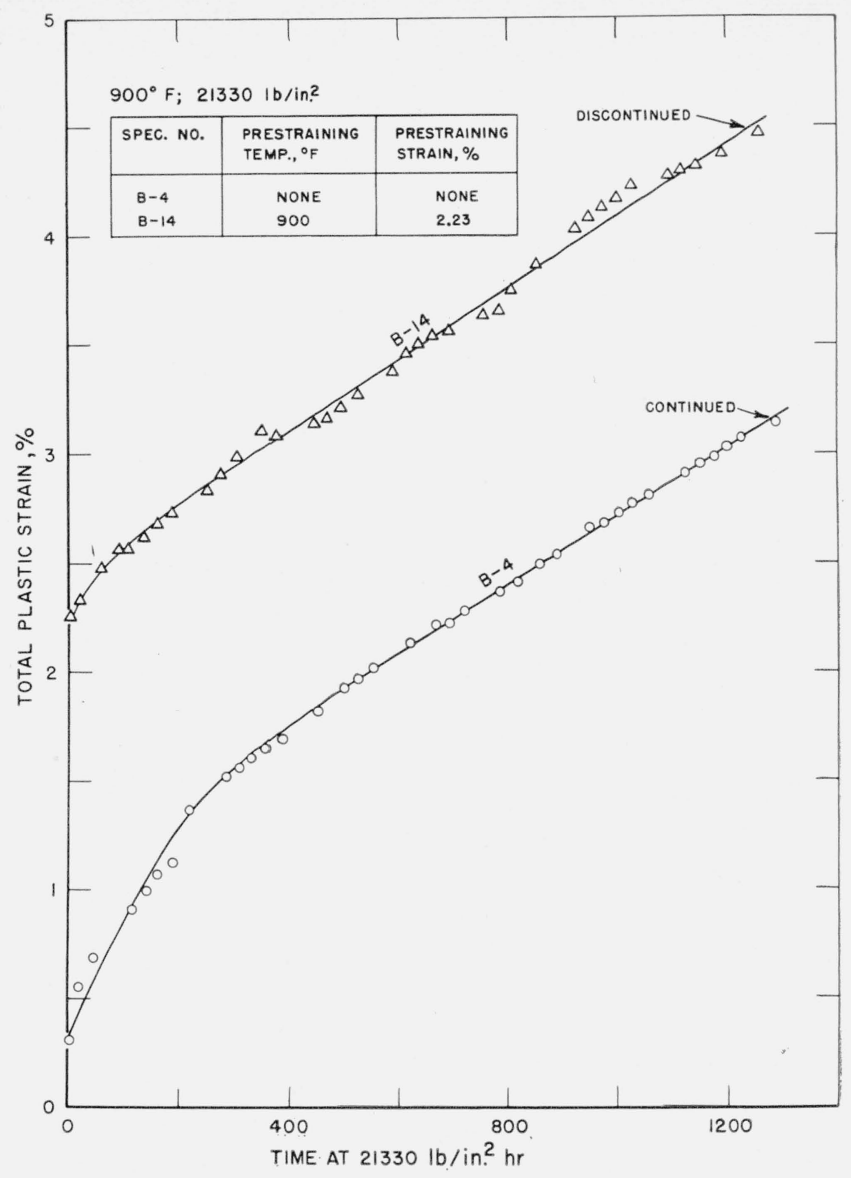

FIGURE 23. Influence of prestraining at $900^{\circ} \mathrm{F}$ on the straintime relations of specimens of 70-percent-Ni-30-percent-Cu alloy tested with a stress of 21,330 lb/in'.

For rate of loading schedule of specimen B-14, see table 5 .

or reduction of area. Increasing the amount of prestrain at $300^{\circ}$ or $900^{\circ} \mathrm{F}$ tended to cause an increase in second-stage creep rate, elongation, and reduction of area for the specimens; whereas the increase in creep rate for the specimens prestrained at $1,200^{\circ} \mathrm{F}$ was accompanied by a decrease in elongation.

Although prior-strain history appeared to have a pronounced effect on the subsequent mechanical properties at $900^{\circ} \mathrm{F}$ of the 30 -percent-Ni-70-percent$\mathrm{Cu}$ alloy, the properties at $300^{\circ} \mathrm{F}$ were practically independent of the rate of loading (tables 3 and 6 ). The latter observation is not in agreement with the results obtained on the 70 -percent-Ni-30-percent-Cu alloy and may be due, in part, to the differences in the degree of strain aging in the metals.

\section{b. Specimen Contour and Post-Test Hardness}

The effect of prior-strain history on the necking characteristics and the post-test hardness of specimens of the 30-percent-Ni-70-percent-Cu alloy, fractured at $900^{\circ} \mathrm{F}$ with a stress of $18,670 \mathrm{lb} / \mathrm{in}^{2}{ }^{2}$ 


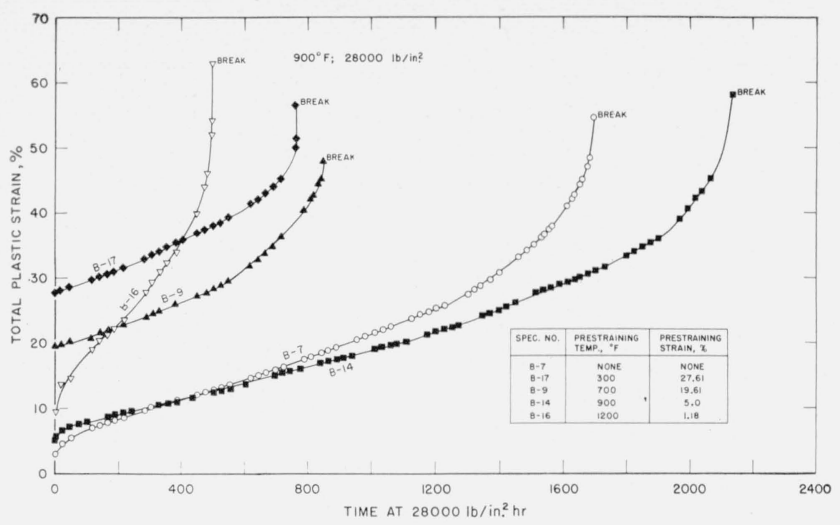

Figure 24. Influence of prior-strain history on the strain-time relations at $900^{\circ} \mathrm{F}$ of specimens of 70 -percent-Ni-30-percent- $\mathrm{Cu}$ alloy tested to complete fracture with a stress of 28,000 $\mathrm{lb} / \mathrm{in}^{2}$.

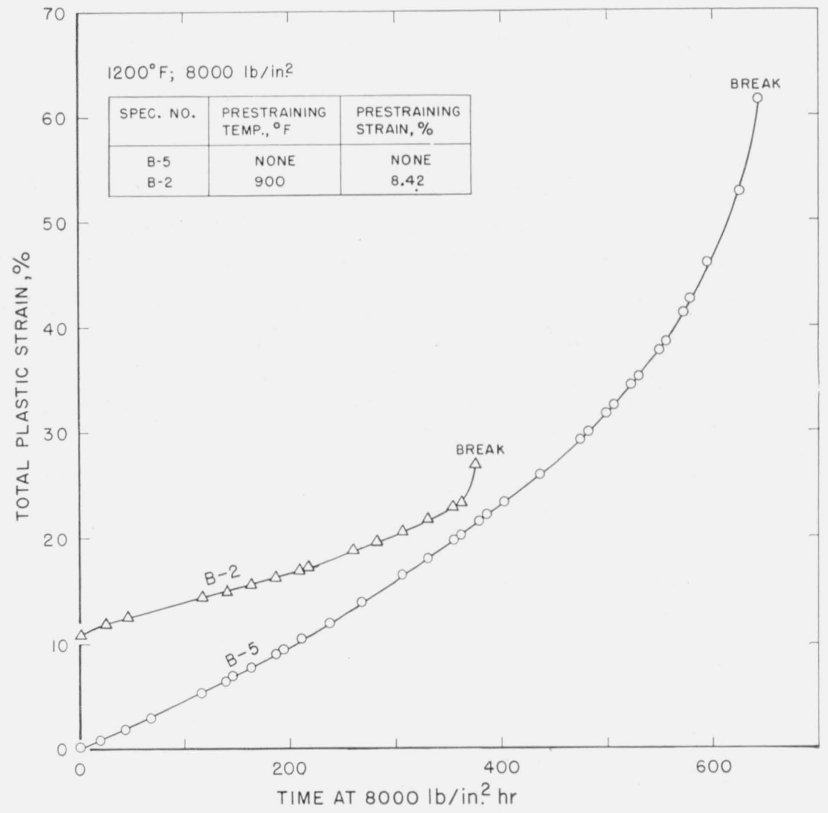

Figure 25. Influence of prior strain history on the strain-time relations at $1,200^{\circ} \mathrm{F}$ of specimens of 70 -percent-Ni-30-percent$\mathrm{Cu}$ alloy tested to complete fracture with a stress of 8,000 $l b / i^{2}$.

is shown in figure 27. No necking of the specimens was observed during the first or second stage of creep. Therefore, it was concluded that the speciment contours after fracture (figure 27a) were due, in part, to the different mechanisms existing in the third stage. A further examination of the data indicates that the specimen contour was affected more by prestraining temperature than by the subsequent second-stage creep rate. For example, the greatest tendency to neck was shown by specimen $\mathrm{C}-24$ and the least tendency by specimen $\mathrm{C}-13$. The prestraining temperature of the latter specimen was $1,200^{\circ} \mathrm{F}$ and the second stage creep rate ex-

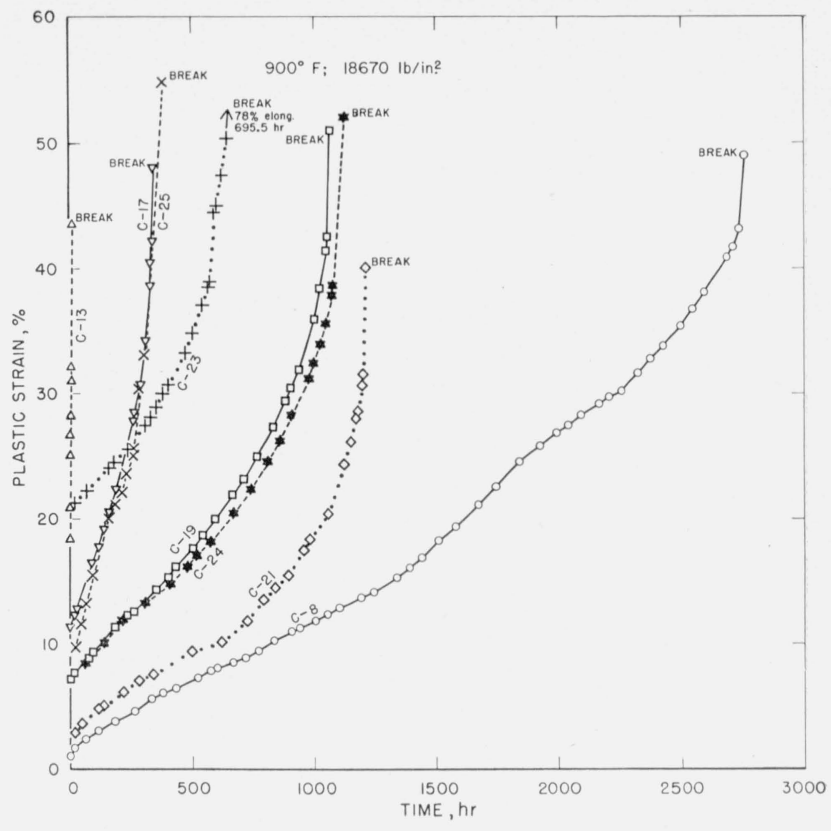

FiguRE 26. Effect of prior strain history on the strain-time relations at $900^{\circ} \mathrm{F}$ of specimens of 30 -percent-Ni-70-percent$\mathrm{Cu}$ alloy tested to fracture with a stress of $18,670 \mathrm{lb} / \mathrm{in}^{2}$.

\begin{tabular}{|c|c|c|c|}
\hline $\begin{array}{l}\text { Specimen } \\
\text { number }\end{array}$ & $\begin{array}{l}\text { Prestrain } \\
\text { tempera- } \\
\text { ture }\end{array}$ & Prestrain & $\begin{array}{l}\text { Avg. creep } \\
\text { rate, sec- } \\
\text { ond stage }\end{array}$ \\
\hline $\begin{array}{l}\mathrm{C}-8 \\
\mathrm{C}-23 \\
\mathrm{C}-24 \\
\mathrm{C}-19 \\
\mathrm{C}-17 \\
\mathrm{C}-21 \\
\mathrm{C}-13 \\
\mathrm{C}-25\end{array}$ & $\begin{array}{c}\circ F \\
\text { None } \\
300 \\
300 \\
700 \\
900 \\
900 \\
1,200 \\
1,200\end{array}$ & $\begin{array}{c}\text { Percent } \\
\text { None } \\
20.7 \\
7.74 \\
7.33 \\
10.12 \\
0.865 \\
10.22 \\
2.374\end{array}$ & $\begin{array}{c}\% / 1,000 h r \\
9.5 \\
19.2 \\
18.0 \\
21.5 \\
57 \\
11.6 \\
905 \\
60\end{array}$ \\
\hline
\end{tabular}

ceeded that of the former specimen, which was prestrained at $300^{\circ} \mathrm{F}$, by a factor of about 50 . In general, prestraining at the lower temperatures increased the severity of the neck, the post-test hardness (fig. 27B), and the rate of strain hardening. It is evident that both the strain-hardening and necking characteristics of the specimens, tested under the same conditions, were strongly dependent on the initial structure, temperature, and chemical composition of the metal.

\section{Summary}

Creep tests were made at $300^{\circ}, 700^{\circ}, 900^{\circ}$ and $1,200^{\circ} \mathrm{F}$ on initially-annealed specimens of copper, nickel, and 70-percent-Ni-30-percent- $\mathrm{Cu}$ and 30percent-Ni-70-percent-Cu alloys. The study was extended to include an evaluation of the rate of loading and prior-strain history on the creep characteristics, hardness, and contours of specimens of the two alloys. 

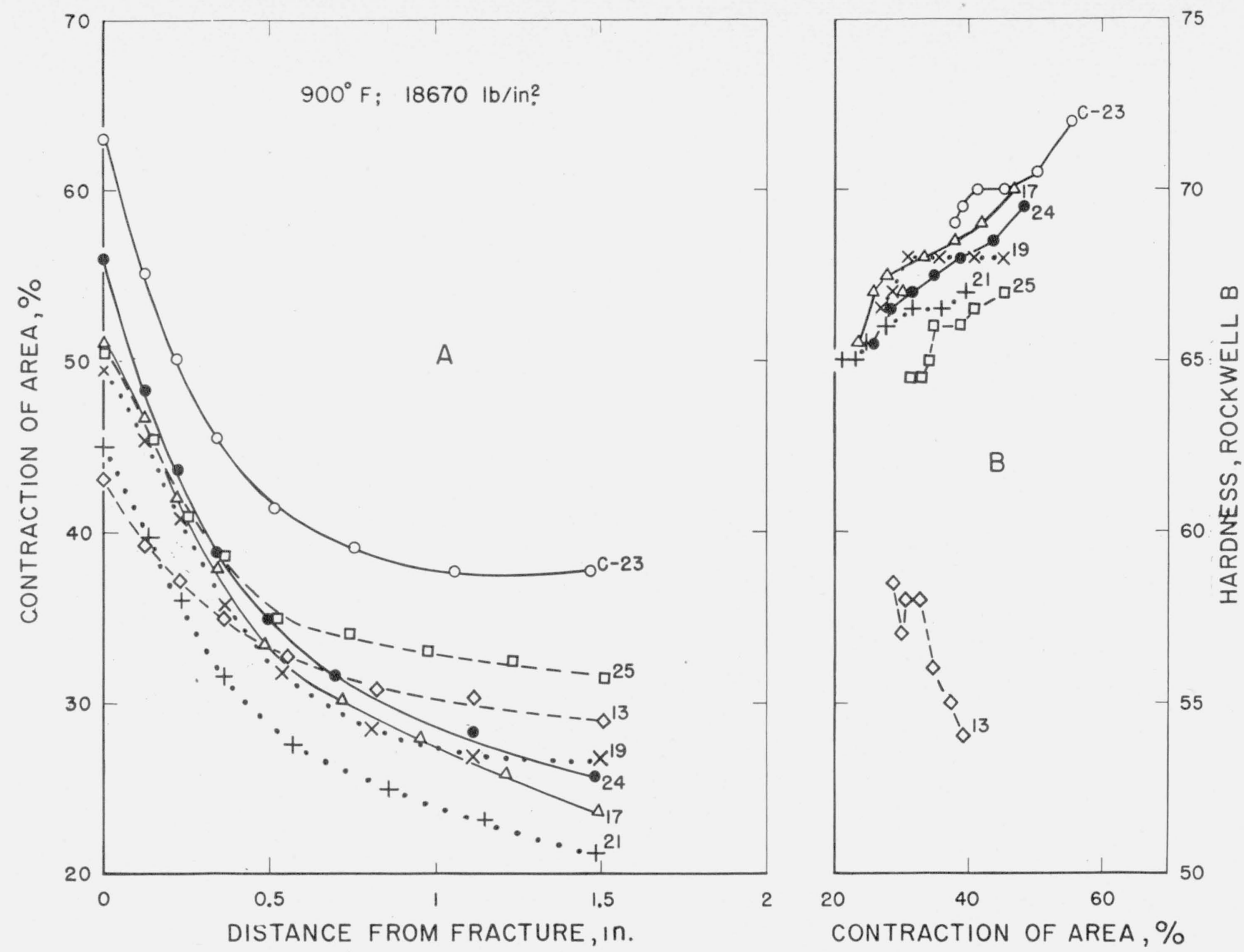

Figure 27. Effect of prior-strain history on specimen contour and hardness distributions of specimens of 30-percent$\mathrm{Ni}-70$-percent-Cu alloy tested to fracture at $900^{\circ} \mathrm{F}$ with a stress of $18,670 \mathrm{lb} / \mathrm{in}^{2}$.

Refer to figure 26 for prior strain history and second-stage creep rates of the specimens.

The initial resistance to flow was increased by alloying the component metals. The maximum resistance was obtained in specimens of the 70percent-Ni-30-percent-Cu alloy.

Conformance to both the theory of exhaustion and of generation of lattice defects during the first stage of creep was obtained over limited ranges of temperatures and stresses.

The shape of the stress-creep rate curves during the first and second stages was altered markedly as the test temperature was increased.

The stress dependence of second stage creep rate was interpreted on the basis of a hyperbolic sine law based on the chemical-rate theory. Strict conformance was limited by the relative balance between strain hardening and recovery of the specimens at the different temperatures. At the same temperature the resistance to creep in the second stage was highest for the 70-percent-Ni-30-percent-Cu alloy and lowest for the copper; however, the increase in creep resistance above that of the component metal was greater when 30 percent of nickel was added to the copper than when 30 percent of copper was added to the nickel.

The creep characteristics of the specimens conformed closely to a theory based on a Cottrell effect at low temperatures and to a theory based on recovery at high temperatures; for specimens tested at low stresses, the results were not easily explainable by either of these theories.
With the exception of the copper specimens tested at $900^{\circ} \mathrm{F}$, the creep rates or fracture times of each metal were expressed in terms of single parameters which varied monotonically with values of the applied creep stress.

Elongation or reduction of area values of the alloys was intermediate between the high values for the nickel and low values for the copper.

Post-test hardness values and the rate of strain hardening of the alloys decreased and the tendency toward uniform contraction of specimens increased with increase in temperature or decrease in secondstage creep rate.

Strain aging induced by slowly loading specimens at $300^{\circ} \mathrm{F}$, was more pronounced for the 70 -percent$\mathrm{Ni}-30$-percent-Cu than for the 30-percent-Ni-70percent-Cu alloy or for that previously obtained for the nickel.

In general, the shape of the creep curves, mechanical properties, and the fracture times were apparently affected by the substructure induced in the specimens by prestraining; however, all phases of Wood's theory of subgrain formation were not generally in agreement with present data.

Prestraining the specimens at the higher temperatures reduced the post-test hardness values, the rate of strain hardening, and the tendency toward a formation of an acute neck. 


\section{References}

[1] W. D. Jenkins and T. G. Digges, Creep of high-purity copper, J. Research NBS 45, 153 (1950) RP2121.

[2] W. D. Jenkins and T. G. Digges, Creep of annealed and cold-drawn high-purity copper, J, Research NBS 4\%, 272 (1951) RP2254.

[3] W. D. Jenkins and T. G. Digges, Effect of temperature on the tensile properties of high-purity nickel, J. Research NBS 48, 313 (1952) RP2317.

[4] W. D. Jenkins and T. G. Digges, Influence of prior strain history on the tensile properties and structures of high-purity copper, J. Research NBS 49, 167 (1952) RP2354.

[5] W. D. Jenkins, T. G. Digges, and C. R. Johnson, Creep of high-purity nickel, J. Research NBS 53, 329 (1954) RP2551.

[6] W. D. Jenkins, T. G. Digges, and C. R. Johnson, Effect of temperature on the tensile properties of a commercial and a high-purity 70-percent-nickel-30-percentcopper alloy, J. Research NBS 54, 21 (1955) RP2561.

[7] W. D. Jenkins, T. G. Digges, and C. R. Johnson, Tensile properties of copper, nickel, and 70-percent-copper30-percent-nickel and 30-percent-copper-70-percentnickel alloys at high temperatures, J. Research NBS 58, 201 (1957) RP2753.

[8] E. R. Parker and T. H. Hazlett, Principles of solution hardening, Seminar on Relation of Properties to Microstructure, Am. Soc. Metals, p. 30 (1953).

[9] T. H. Hazlett and R. D. Hansen, Influence of substructure on the shape of the creep curve, Trans. Am. Soc. Metals 4\%, 508 (1955).

[10] R. S. French and W. R. Hibbard, Jr., Tensile deformation of copper, Trans. Am. Inst. Mining Met. Engrs, 188, $53(1950)$.

[11] C. S. Barrett, Structure of metals, 2d ed., p. 220 (McGraw-Hill Book Co., New York, N. Y., 1952).

[12] B. L. Averbach, The structure of solid solutions, Seminar on Theory of Alloy Phases, Am. Soc. Metals, p. 301 (1955).
[13] J. C. Fisher, On the strength of solid solution alloys, Acta Metallurgica 2, 9 (1954).

[14] A. H. Cottrell, Interactions of dislocations and solute atoms, Seminar on Relation of Properties to Microstructure, Am. Soc. Metals, p. 131 (1953).

[15] E. N. da C. Andrade, The creep of metals, Report of a Conference on Strength of Solids, Phys. Soc. p. 20 (1948).

[16] M. Davis and N. Thompson, Creep in a precipitationhardened alloy, Proc. Phys. Soc. [B] 63, 847 (1950).

[17] A. Nadai and P. G. MeVetty, Hyperbolic sine chart for estimating working stresses of alloys at elevated temperatures, Proc. Am. Soc. Testing Materials, 43, 735 (1943).

[18] H. Eyring, The activated complex in chemical reactions, J. Chem. Phys. 3, 107 (1935).

[19] F. R. Larson and J. Miller, A time-temperature relationship for rupture and creep stresses, Trans. Am. Soc. Mech. Engrs. 74, 765 (1952).

[20] E. S. Machlin, Creep-rupture by vacancy condensation, J. of Metals, Trans. Am. Inst. Mining Met. Engrs. 8, 106 (1956).

[21] B. R. Coles, The Lattice spacings of nickel-copper and palladium-silver alloys, J. Inst. Metals 84, 346 (1956).

[22] J. Weertman and P. Shahinian, Creep of polycrystalline nickel, J. of Metals, Trans. Am. Inst, Mining Met. Engrs., 8, 1223 (1956).

[23] M. J. Manjoine and W. L. Mudge, Jr., Creep properties of annealed unalloyed zirconium, Proc. Am. Soc. Testing Materials, 54, 1050 (1954).

[24] P. Ludwik, Elemente der Technologischen Mechanik (Julius Springer, Berlin, 1909).

[25] W. A. Wood, Creep processes, Symposium on Creep and Fracture of Metals at High Temperatures, Natl. Phys. Lab. (1956).

Washington, August 1, 1957. 